\title{
Unpacking reputational power: Intended and unintended determinants of the assessment of actors' power
}

\author{
Manuel Fischera, Pascal Sciarinib
}

aDepartment of Environmental Social Sciences, Swiss Federal Institute for Aquatic Research, Überlandstrasse 133, 8600 Dübendorf, SwitzerlandbDepartment of Political Science and International Relations, University of Geneva, 40 Boulevard du Pont-d'Arve, 1204 Geneva, Switzerland

\begin{abstract}
The idea behind the reputational measure for assessing power of political actors is that actors involved ina decision-making process have the best view of their fellows' power. There has been, however, no sys-tematic examination of why actors consider other actors as powerful. Consequently, it is unclear whetherreputational power measures what it ought to. The paper analyzes the determinants of power attributionand distinguishes intended from unintended determinants in a data-set of power assessment covering10 political decision-making processes in Switzerland. Results are overall reassuring, but neverthelesspoint toward selfpromotion or misperception biases, as informants systematically attribute more powerto actors with whom they collaborate
\end{abstract}

\section{Keywords:}

Reputational power, validity, ERGM, network, collaboration

This document is the accepted manuscript version of the following article:

Fischer, M., \& Sciarini, P. (2015). Unpacking reputational power: intended and unintended determinants of the assessment of actors' power. Social Networks, 42, 60-71. https://doi .org/10.1016/j. socnet.2015.02.008

This manuscript version is made available under the CC-BY-NC-ND 4.0

1icense http://creativecommons.org/licenses/by-nc-nd/4.0/ 


\section{Introduction}

The reputational measure for assessing power of political actors has been used for decades in studies on public policy, policy networks and political decision-making (e.g. Fernandez and Gould, 1994; Fischer et al., 2009; Henry, 2011; Ingold, 2011; Knoke et al., 1996; Kriesi et al., 2006; Matti and Sandström, 2011; Sciarini et al., 2004). The basic underlying idea of reputational power is that actors belonging to a given political system or involved in a specific decision-making process have the most accurate view of how power is allocated among actors. Reputational power is most often used in its aggregated form: The score of reputational power of a given actor is computed as the sum (or the mean) of power attributions granted to this actor.

By so doing, one fails to recognize that power assessment is relational in nature and should be analyzed accordingly, that is, through a network perspective. In addition, reputational power is also inherently subjective, as it is based on the mutual evaluation of power among political actors. Therefore, when asking a political actor about the power of its fellows, one does not know on which criteria the informant's assessment is based. An informant may consider another actor as powerful for several - good - reasons: because the latter has formal authority, because it has access to several institutional arenas of decision-making, because it has lots of allies, or because of its agenda-setting power. These elements capture parts of what the reputational measure is supposed to capture. However, an informant may also consider another actor as powerful for less good reasons, which would affect the assessment of reputational power. Thus, actors should not systematically attribute more power to each other simply because they share some similarity or because they collaborate.

We suggest that such unintended determinants of power attribution may be the result of either deliberate self-promotion (Pfeffer et al., 2006; Tal-Or, 2010) or a perception bias (Kitts, 2003; Leach and Sabatier, 2005). On the one hand, informants may intentionally overstate the power of fellows with whom they share some similarities or with whom they closely collaborate, in 
order to indirectly promote themselves. On the other hand, informants may suffer from a perception bias, that is, they may truly believe that similar or close fellows are more powerful than they are in reality. Either way, this affects the construct validity (Cronbach and Meehl, 1955) of the reputational power measure, which does no longer measure what it ought to.

In other words, one should be aware that reputational power is likely to capture both intended and less intended factors. To our knowledge, the question regarding whether and to what extent reputational power measures what it ought to measure has been hardly addressed thus far. It is, however, of utmost importance. First, given that reputational power is so extensively used in empirical studies, it is crucial to know more about the underlying determinants and about the possible weaknesses of the measure. Second, identifying the unintended determinants will be of great help for researchers that are planning to use this measure, as it can give important hints on how to design a survey and on how to overcome - or to control for - these unintended factors.

Against this background, the purpose of the paper is to identify the determinants of reputational power attribution. More specifically, we wish to analyze whether reputational power measures what we intend to measure. To that end, we apply Exponential Random Graph Models (ERGM) to a unique network data-set covering the 10 most important decision-making processes of the early 2000s in Switzerland. Nodes of the networks are collective political actors such as administrative agencies, interest groups, political parties, or cantons. Data stem from approximately 230 face-to-face interviews conducted with representatives of these collective actors. The data-set offers systematic information regarding both the network of reputational power assessment as well as the likely determinants attribute-related and relation-related - of power attribution for each of the 10 decision-making processes under study. It thus enables us to identify the sources of reputational power assessment across a range of policy processes, which obviously increases the confidence in our findings. In addition, it also allows us to evaluate whether collaboration in other decision- 
making processes as a specific form of "multiplexity" is likely to bias power assessment in the process of interest.

The remainder of this paper is structured as follows. Our analytical framework appears in section 2. We develop our theoretical argument regarding the strengths and weaknesses of the measure of reputational power. From that we derive our hypotheses regarding the unintended determinants of the measure. Section 3 presents the data, the method, and the models. Results appear in section 4 , section 5 concludes.

\section{Analytical framework}

Power is one of the most fundamental but also most controversial concepts in political science. Consequently, it has been defined and measured in a myriad of different ways (e.g. Bachrach and Baratz, 1962; Bates, 2010; Dahl, 1957, 1961; Emerson, 1962; Lukes, 1974; Scott, 1994). According to Max Weber's famous definition "power means every opportunity, within a social relationship, to enforce one's own preference despite resistance." (Weber 1980, cited in Weiss, 1996). This definition fits well to a policy-making perspective: On the one hand, power means exerting influence on other actors; on the other hand, it means influencing policy decisions (see Knoke et al., 1996).

\section{Assessing reputational power: Theoretical and methodological considerations}

In political science and political sociology the use of the reputational measure to evaluate the power of political actors has a long tradition. Originating in the US community power literature in the 1960s (e.g. Dahl, 1961; Emerson, 1962; Gamson, 1966; Laumann and Knoke, 1987; Laumann and Pappi, 1976), the measure of reputational power has also been extensively used in policy analysis, this in a variety of countries and policy domains (e.g. Fernandez and Gould, 1994; Fischer et al., 2009; Henry, 2011; Ingold, 2011; Knoke et al., 1996; Kriesi et al., 2006; Matti and Sandström, 2011; Sciarini et al., 2004). For instance, 
Knoke et al. (1996) compare networks of labor market policy in different countries and assess the relative power of the state and interest groups. Sciarini et al. (2004) compare Europeanized and domestic decision-making processes in Switzerland and, based on the reputational method, find that state actors are more powerful in the former than in the latter. Henry (2011) uses the measure in order to analyze whether the perceived influence of an actor makes this actor more attractive as a cooperation partner for others. Besides political science, other research domains rely on the concept of reputation. For example, the domains of organization and management studies rely on the concept of corporate reputation in order to measure the public image or identity of a firm and its attractiveness to investors, clients or employees (Barnett and Pollock, 2012; e.g., Ponzi et al., 2011; Walker, 2010; Walsh and Beatty, 2007). ${ }^{1}$

To gather reputational data, researchers typically rely on face-to-face interviews and postal or online questionnaires. They ask collective actors - or, more specifically, representatives of collective actors - to name those actors that, in their view, are very influential in a specific political system or a given decision-making process. ${ }^{2}$ This data gathering results in a binary matrix with the same set of actors on both dimensions. ${ }^{3}$ On the horizontal dimension, actors are "active" as informants about their fellows' power. In the terminology of network analysis, they are "egos" or "senders" of ties, in that case of reputation attribution. On the vertical dimension, the same actors are "passively" evaluated by their fellows, that is, they are "alters" or "receivers" of power attribution. The reputational power of each actor is then derived from the data: The score of reputational power of each actor corresponds to the sum (or the mean) of power judgments that this actor receives. ${ }^{4}$ The resulting reputational power indicator is then mostly used in its aggregated form. Corporate reputation is measured in the same way, i.e. by assessing stakeholders' perceptions and calculating the aggregated perception of all stakeholders (Walker, 2010). 
Critical discussions of the measure of reputational power are as old as its applications. The measure has two main strengths. First, reputational power is supposed to be close to reality, because it relies on judgments of actors that are directly involved in the political system or decision-making process, and are therefore best positioned to evaluate their fellows' power. ${ }^{5}$ Second, the reputational measure is supposed to provide an encompassing view of power, no matter where power comes from. The fact that the measure is based on the evaluation of actors that directly participate in a decision-making process helps to uncover parts of the "hidden" face of power (Bachrach and Baratz, 1962). That is, it helps to take into account elements of power that are hardly measurable otherwise, like actors ${ }^{\star}$ agenda-setting power, their ability to avoid the public discussion of certain subjects, or their influence due to financial resources. ${ }^{6}$ In other words, the measure can account for elements that are hardly visible to an outside observer.

The encompassing nature of reputational power is however not only an asset, but also a weakness. It is argued that the measure is problematic because it is difficult to make sure that the researcher and the informants share the same definition of power (Knoke, 1998; Wolfinger, 1960). Given this, there is a risk that the researcher relies on data from informants who are not aware of the different aspects of power and/or who use different criteria when forming their judgments. For this reason, the corporate reputation literature splits up the measure in order to capture different aspects of corporate reputation (Walker, 2010; Walsh and Beatty, 2007). What is more, modern political decision-making is highly complex, involves many actors and events that influence policy outcomes, and the relevant action in the policy process often takes place behind the scene. Even if informants are part of the game, they may nevertheless find themselves in a situation of incomplete information (Heaney, 2014). To some extent, they also have to "guess" who is powerful and who is not. While they may base their judgment on some reliable cues, they may also use less favorable criteria. 
Among others, they may misperceive their fellows' power or they may use the reputational measure instrumentally, in order to emphasize their own power.

\section{Intended and unintended determinants of reputational power attribution}

As mentioned above, reputational power is most often used in its aggregated form in policy analysis. By doing so, one fails to take into account important information regarding which actors (as "informants") deem which other actors powerful. More specifically, by focusing on the total or average amount of power granted to a given actor one overlooks the fact that power evaluation is inherently relational, and that the receiver and the sender are embedded in a set of relations that are likely to influence power assessment. Of course, one should not worry if an actor is seen as powerful by informant $a$, and less so - or even not all - by informant $b$. In fact, being able to take into account a variety of evaluations is one of the main strengths of the reputational power measure. However, what one should worry about is if power attribution is systematically biased for a specific part of interview partners only, as a result of network effects.

Construct validity (Cronbach and Meehl, 1955) refers to whether a measure actually measures what it ought to. In their discussion of measurement errors, King et al. (1994) show that any systematic measurement error, such as a consistent over- (or under-) estimate of a given unit, will result in biased descriptive statistics. Whether a systematic measurement error will further bias causal inference depends on whether the error holds for the whole sample or only for part of the sample. In the former case, causal inference will not be biased as the measurement error affects all units to the same extent. If, however, there is a systematic error in one part of the sample only, then causal inference will be biased. ${ }^{7}$

According to our general assumption the second variant, i.e. a systematic error in one part of the sample only, is at work in the process of power attribution, as specific types of egos are likely to systematically overstate the power of their alters. We further suggest that such a 
systematic bias stems from actors' self-promotion or from actors' misperception. Before developing further our argument, let us first discuss the intended determinants of power attribution. By intended determinants, we mean actual and fairly undisputed sources of actors' power such as actors' formal authority, their centrality in the policy network, their level of access to decision-making arenas, as well as other less factors effects like agenda-setting power, which informants are supposed to take into account when assessing their fellows' power.

\section{Intended determinants}

Formal authority is a statute that characterizes some specific categories of actors. In Switzerland, as in many Western democracies, three categories of actors are especially powerful in a decision-making process because they are able to influence both the process as well as other actors. First, state actors, i.e. executive and administrative units of the central state responsible for a given decision-making process, enjoy formal authority (Laumann and Knoke, 1987). They have a certain leeway regarding how to design the decision-making process and they can substantially influence the content of a legislative proposal, this especially in the preparatory phase of legislation - from the very beginning of a process (drafting of a pre-proposal) up to the bill proposal that they then transmit to the parliament. Second, governing parties are not only represented in government, but also dominate the parliament. They therefore have a decisive influence on the negotiations and decisions in the parliamentary phase, whose importance has increased over time (Sciarini, 2014). Third, peak associations are usually seen as being very powerful in the corporatist-like political system of Switzerland with its long-lasting tradition of negotiations among non-state actors, and between non-state actors and state executives (e.g. Katzenstein, 1985; Kriesi and Trechsel, 2008). Peak associations have important financial and organizational resources, and they are 
active in the preparatory phase of decision-making processes. In addition, they are also credible veto-players, as they are able to challenge a policy project in a referendum vote. ${ }^{8}$

Next, from the perspective of the policy process the institutional arenas of the decisionmaking process create a "political opportunity structure" for actors, one that helps them to influence a decision-making process (Kriesi, 1995). More specifically, it is argued that actors that are granted access to many decision-making arenas will take advantage of this and will be reinforced. Decision-making arenas can take the form of working groups, consultation procedures or parliamentary committees and create opportunities for actors' participation and influence. Actors getting access to many decision-making arenas are more able to influence the outcome, and should therefore be seen as more powerful than actors with less access.

Finally, political actors seek collaboration with others in order to improve their position in collective action dilemmas and to translate their goals into policy (Leifeld and Schneider, 2012). An actor's position in a policy network of cooperation ties ("structural embeddedness", Granovetter, 1985) is supposed to influence its power. More specifically, occupying a central position in a network gives an actor access to other actors' resources or information. Additionally, a central actor gains control possibilities over the flow of resources or information, which is also conducive to power (Knoke, 1990; Knoke et al., 1996).

\section{Unintended determinants: Self-promotion and misperception bias}

In a recent paper, Heaney (2014) has argued that the embeddedness of political actors in multiplex networks is an important explanation for the variation in reputational power granted to these actors. Multiplex networks are critical in helping interest groups to resolve uncertainty about which other interest groups are powerful: The more actors communicate, collaborate or are involved in the same issue area, the more they assign power to each other. We agree with Heaney (2014) that multiple ties may help actors to gather information regarding actors with whom they are connected and, therefore, reduce uncertainty regarding 
who is powerful and who is not. However, having more information about some actors should not necessarily lead informants to consider these actors as more powerful. On the contrary, more information on another actor should also help informants to recognize the weaknesses of other actors and, therefore, to consider them as less powerful.

There are at least two possible mechanisms that may provide the missing link, i.e. that may lead informants to attribute more power to their fellows: Self-promotion and misperception. First, self-promotion is an important phenomenon in the social psychology literature and describes situations where individuals make positive assertions about themselves (Pfeffer et al., 2006; Tal-Or, 2010). The phenomenon has been widely studied, for example in the context of interactions among kids (Aloiseyoung, 1993; Watling and Banerjee, 2007) or within business organizations (Molleman et al., 2012; Proost et al., 2010). Direct selfpromotion, however, is a risky strategy as the self-promoter is perceived negatively (Pfeffer et al., 2006; Tal-Or, 2010). By contrast, indirect self-promotion allows individuals to avoid the negative consequences of self-promotion by indicating connections to successful others or by mentioning the success and accomplishments of others to whom they are already connected (Tal-Or, 2010). Applying this argument to the assessment of reputational power, we expect actors to intentionally overstate the power of alters with whom they share some characteristics, in order to indirectly promote themselves. Second, a bias in power attribution may also occur accidentally, as a result of ego-centric misperception (Kitts, 2003). More specifically, we assume that egos sharing some characteristics with alters may believe in good faith that these alters are more powerful than they are in reality (Leach and Sabatier, 2005; Weible et al., 2011). While both biases are different in nature (the first originates from deliberate self-promotion, and the second from a perception bias), they both affect the validity of the reputational measure.

Note further that self-promotion and misperception also have different implications. In the case of self-promotion, ego does not really believe that alter is powerful, but rates alter "as if" 
it were powerful for instrumental reasons, i.e. to indirectly increase its own power. However, ego will then not behave as if alter were powerful. By contrast, if ego suffers from misperception and truly believes that alter is powerful, then ego will behave accordingly - and alter will be empowered ("self-fulfilling prophecy"). ${ }^{9}$ Empirically, as we do not look at actors' behavior, we cannot check based on our data whether the bias that we identify stems from self-promotion or misperception - or from another mechanism. Instead, we simply aim at assessing whether unintended factors do affect the reputational power measure.

Two types of network relations may lead to self-promotion or misperception. First, we assume that actors tend to - deliberately or not - attribute more power to actors with whom they share some attributes ("homophily bias"). Shared attributes, in turn, may relate to status or to preferences. Second, we assume that actors assign more power to others they collaborate with (collaboration bias). Ceteris paribus, if we see that homophily and/or collaboration affect power attribution, i.e. that sharing similarities or collaborating closely systematically leads to overstate the power of a fellow actor, this will be indicative of unintended determinants in the measurement of reputational power. Controlling for a number of intended factors should allow us to isolate these unintended factors. Below we briefly elaborate on the two possible sources of bias, starting with homophily.

Homophily refers to ties forming between two actors that share some sort of similarities (see e.g. Goodreau et al., 2009). Homophily can be of objective nature (such as actor type homophily) or of subjective nature (such as preference homophily). Regarding first actor type homophily, we assume that the actors' statute influences their assessment of reputational power. Due to the specific "lenses" through which they see the decision-making process, political actors are likely to attribute more influence to actors of their own actor type. Thus, we may assume that state executive actors are particularly sensitive to "their" contribution (e.g., in the pre-parliamentary phase), whereas political parties tend to emphasize the work they do in the parliamentary arena. Irrespective of whether this mechanism originates from 
self-promotion or from misperception, it will lead egos to attribute more power to alters belonging to the same actor type, than to alters not belonging to the same type.

H1: Actors of the same actor type attribute more power to each other than actors that are not of the same actor type.

Turning to preference homophily, we assume that sharing similar preferences concerning a policy project may also influence power assessment, as informants' beliefs filter their perceptions (Knoke, 1998). According to the "angel shift" perspective (Leach and Sabatier, 2005; Weible et al., 2011), actors with converging policy preferences are likely to see each other as especially powerful. In line with this argument, we assume that preference homophily may also affect power attribution.

H2: Actors sharing similar policy preferences attribute more power to each other than actors with dissimilar preferences.

The argument that actors sharing some sort of characteristics are likely to consider each other as especially powerful may be extended to collaboration between actors. Collaboration may also affect power assessment, as a result of either indirect self-promotion or perception bias. Thus, we assume that political actors that collaborate closely with each other in a given process tend to consider each other as more powerful than actors that do not collaborate.

H3: Actors that collaborate closely attribute more power to each other than actors that do not collaborate.

Finally, we join the view that multiplexity may also be conducive to biased judgments of reputational power (Heaney, 2014), and we draw attention to a specific form of multiplexity arising from network ties in parallel decision-making process. In our view, multiplexity does not only take the form of various network ties (e.g. information, advice, collaboration) in a 
given policy domain. It may also stem from ties that actors have developed (or are developing) in parallel decision-making processes. In order to understand why an actor $i$ attributes power to an actor $j$, it is thus important to look at other, parallel relations between these two actors. More specifically, we argue that multiple ties arising from collaboration in separate, parallel decision-making processes have the same effects as multiplex networks within a given policy domain. That is, they will lead informants to attribute more power to alters with whom they collaborate closely in these parallel networks, than to actors with whom they do not collaborate in parallel networks.

H4: The higher the number of other, parallel decision-making processes in which two actors collaborate, the higher the likelihood that these actors attribute power to each other in the network of interest.

\section{Data, method, and models}

\section{Data}

Our empirical tests are based on data regarding the 10 most important political decisionmaking processes in Switzerland between 2001 and 2006. ${ }^{10}$ The 10 processes are the $11^{\text {th }}$ pension reform (number of actors in the network: 23), the program of budget relief 2003 (25), the extension of the bilateral agreement on the free movement of persons and flanking measures (26), the bilateral agreement on the taxation of savings (19), the bilateral agreement on Schengen/Dublin (26), the law on nuclear energy (24), the new law on foreigners (20), the reform of fiscal equalization and tasks distribution (24), the new constitutional articles on education (20) and the law on telecommunication (22). The fact that our analysis covers a wide range of different policy domains oviously increases the generalizability of our results. Data were gathered through approximately 230 semi-structured face-to-face interviews with representatives of the main collective actors (administrative units, political parties, interest groups, cantons) involved in the processes. ${ }^{11}$ To identify the main collective actors we relied 
on the classic combination of decisional, positional and reputational approaches (Knoke, 1993). ${ }^{12}$

The outcome network of the analysis is given by directed ties of reputation assessment among actors involved in the respective decision-making process. As explained above, focusing on aggregated reputational power and treating it as an attribute means that one throws away crucial information regarding both the relational nature of power assessment and the characteristics of informants. As power assessment is inherently a network relation between two actors, the information included in the power attribution matrix must be considered as a directed network ${ }^{13}$ of reputation assessments between actors, and it must be analyzed accordingly. The network of reputational power stems from a question raised during our interviews: We asked our interview partners to indicate, from a list of actors that participated in a given decision-making process, which actors were very influential (1) or not influential (0). ${ }^{14}$ We systematically explained that being very influential in a decision-making process means to be able to substantially influence the output of the decision-making process.

\section{Exponential Random Graph Models}

To identify the determinants of power attribution we estimate Exponential Random Graph Models (Robins et al., 2007; ERGM, Wasserman and Pattison, 1996; Wasserman and Robins, 2005). ERGMs calculate the probability of an observed network, given a set of statistics on

the network, compared to all networks that could have been observed. ${ }^{15}$ Because network data usually involve mutual dependence of observations, standard statistical models are inappropriate (e.g. Cranmer and Desmarais, 2011; Goodreau et al., 2009). ERGMs therefore include three types of effects, i.e. node covariates, edge covariates, and endogenous network structures. The first describe nodes (that send or receive ties), and the second are attributes of ties between two nodes. The third type of effect, i.e. local network structures, are supposed to endogenously influence the outcome network. Therefore, tie probabilities are dependent on 
the network itself. This dependence is however not a weakness but an inherent feature of ERGMs and is not treated as a noise parameter, but explicitly modeled (Goodreau et al., 2009). Because of this dyadic dependence, the models are estimated using Markov chain Monte Carlo simulation methods (MCMC), which generate a sample from the space of possible networks to estimate the parameters maximizing model likelihood. The MCMC algorithm proceeds by comparing the probability of a new randomly selected proposed network to the current one in the chain, then deciding whether to accept the proposed network as the next step in the chain or not (Morris et al., 2008). Models 1 and 2 in the paper as well as models 1-3 in the appendix are based on MCMC estimation. Model 4 in the appendix, on the contrary, does not include endogenous network structures. It is therefore similar to traditional logistic or log-linear models, and parameters are based on maximum likelihood estimations.

\section{Variables and models}

Our models enable us to test our hypotheses regarding the unintended determinants of the reputational power measure. To that end, they include variables that capture both intended and unintended factors. Starting with the latter, remember that according to our hypotheses the homophily bias may take two forms: actor type homophily and preference homophily. Accordingly, we first group actors of the same type in four categories: state actor, political party, interest group, and a residual category of other actors. A "nodematch"-term then captures whether two actors belong to the same actor type. Second, the similarity of actors' preferences is based on interview data. Actors were asked to select, from a list of actors participating in the process, those actors with whom they had convergent or divergent preferences about the specific project. ${ }^{16}$ This information is represented as a network whose ties express convergence (1) or divergence (-1) of opinions and added to the model as an edge covariate term. 
The second variable that is likely to bias power judgments is collaboration (see hypothesis 3). To reconstruct the collaboration network among actors, we asked our interview partners to indicate, from the same list of actors, those with whom they collaborated. ${ }^{17} \mathrm{We}$ did not, however, specify the actual content of the relationship. Indeed, rationales for collaboration can be the exchange of information, advice, or resources, the coordination in a coalition, or the search for access to influential actors (Weible and Sabatier, 2005). Since there is no emerging agreement on the appropriate dimensions of relationships to measure, we focus on a very general collaboration relation rather than seeking to distinguish specialized relationships (Scholz et al., 2008). Further, we rely on a neutral definition of collaboration, i.e. actors can collaborate without necessarily agreeing on the substantive policy issue at stake. We then symmetrized the directed collaboration network with the minimum method, which leaves us with only the collaboration contacts indicated by both actors (i.e. only reciprocated ties). ${ }^{18}$ Finally, the variable for parallel collaboration in other processes (see hypothesis 4) ranges from 0 to 1 and indicates whether two actors collaborate in no other decision-making process (0) or in all the other 9 decision-making processes (1). ${ }^{19}$

Turning to measures of intended determinants, we first introduce a variable measuring formal authority. More specifically, we include three dummy variables indicating whether an actor is a state actor responsible for the project, a government party, or a peak association, respectively. Next, the participation of actors in the different arenas of a decision-making process is based on interview data. From a list containing all the arenas of the decisionmaking process, we asked interview partners to indicate in which arenas their organization participated. Based on this information, we then calculated a participation ratio for each actor for the whole process (percentage of arenas the actor participated over the total number of arenas). Finally, centrality in the collaboration network is based on the collaboration data described above. We rely on degree centrality, which captures the number of (reciprocated) collaboration ties an actor has and, therefore, expresses its basic ability to influence other 
actors and get information from them. All variables are introduced in the model as node covariates.

Further to the variables measuring the unintended factors and those measuring the intended factors that we introduce as controls, our model also includes additional control variables. First, we control for some endogenous network mechanisms. The reciprocity parameter measures to what extent actors have the tendency to reciprocate ties. Reciprocity is given if both actors in a dyad indicate that their partner is powerful, respectively. The GWESP (geometrically weighted edgewise shared partner) and GWDSP (geometrically weighted dyadwise shared partner) parameters take into account triangular structures in the network of reputation assessment. The GWDSP term captures the existence of configurations where actor $a$ attributes power to actor $b$ which attributes power to actor $c$ (whether actor $a$ attributes power to actor $c$ or not). On top of that, the GWESP term measures whether in the same situation, actor $a$ also attributes power to actor $c$. A low geometrical weighting parameter of 0.1 for both parameters avoids model degeneracy (Goodreau et al., 2008; Leifeld and Schneider, 2012; Morris et al., 2008). Second, we control for the fact that interview partners do not all have the same view on how power is distributed, i.e. that some of them might be more generous than others when indicating who they consider as powerful. We do so by including a node covariate variable that corresponds to actors' out-degree centrality in the network of power assessment.

In the empirical tests below, we run two models. The first model includes the endogenous network effects and out-degree centrality as control variables, the formal authority variables (i.e., leading agency, government party, peak association) controlling for the intended determinants and the variables capturing the unintended determinants, namely actor type and preference homophily, collaboration in a given network and collaboration in the other, parallel networks. The second, more complex model adds the other two control variables 
capturing the intended factors, i.e. the centrality of an actor and the intensity of its participation in the arenas of the decision-making process.

\section{Analysis}

Coefficient estimates for the first model appear in table $1 .^{20}$ The same model is estimated for each of the 10 networks of reputation assessment. ${ }^{21}$

\section{Table 1 about here}

Let us start with the endogenous network variables included as controls. The edges parameter in each model is important to control for the density of the network, but does not need to be interpreted substantially. ${ }^{22}$ There is no reciprocity effect in 9 cases and a negative one in one case, i.e. the education reform. The negative effect indicates a hierarchy in the attribution of power, because the attribution of power goes in only one direction. The GWDSP term is negative in all cases but one, which is a further sign of the hierarchical nature of power assessment: Actors who are considered as powerful do not tend to indicate other actors as powerful. Finally, the GWESP term is not significant in any of the ten estimations. Further, the effect of the outdegree of reputation evaluation is significant and positive in all 10 processes, meaning that the more reputation ties actor $a$ sends, the higher the probability to observe a tie on the specific relation between $a$ and $b$, which makes full sense.

Turning to the variables measuring the intended determinants that we also treat as controls, we first see that formal authority has the expected positive impact on power evaluation. Thus, being the leading agency of the state administration has a significant and positive effect on being assessed as powerful in all networks. Similarly, being a government party has a positive effect in all processes but one (that on the taxation of savings). ${ }^{23}$ By contrast, peak associations are deemed more powerful than other actors only in three decision-making 
processes out of 10. This result is, however, in line with the power loss that peak associations have suffered from in Swiss decision-making processes (Sciarini, 2014). ${ }^{24}$ Overall, then, formal authority captures an important share of reputational power.

In the second model (see table 2), we add two further control variables in order to capture more of the intended determinants, namely participation in arenas of the decision-making process and centrality in the collaboration network. Both variables interfere with the measures of formal authority, as actors with formal authority often participate intensely and are central in the collaboration network. This accounts for the fact that formal authority is less important in model 2 than in model 1. Centrality in the collaboration network is strongly conducive to being assessed as powerful; the corresponding coefficient is significant and positive in all processes but one. Intense participation in the arenas of the decision-making process is related to power in five processes out of ten. ${ }^{25}$ Thus, the intensity of participation in institutional arenas and the centrality in the collaboration network have the expected influence on power assessment. In that sense, we can be confident that reputational power measures what it ought to.

\section{Table 2 about here}

Now, the crucial test for the reputational power measure is whether, controlling for both endogenous network effects and intended determinants of reputational power, we witness any determinants of reputation attribution that the measure is not supposed to capture. First, the coefficients regarding actor type homophily (H1) show that this variable has no significant influence in any of the 10 decision-making processes. We can thus reject our first hypothesis. Being of the same type does not prompt actors to attribute more power to their peers.

Second, preference similarity has a significant (and positive) effect in two (table 1) or three (table 2) processes only. Actors with similar preferences consider each other as more 
powerful in the processes regarding education, the taxation of savings, and fiscal equalization (the last only in table 2). On closer inspection, these processes were strongly influenced by rather small groups of individuals that strongly agreed on the basic features of the projects from the outset. Accordingly, preference similarity seems to influence reputation assessment in processes governed by a collaborative context and a problem-solving attitude (Weible et al., 2011). Overall, however, we must reject our hypothesis 2.

To account for this result, we may mention that the "angel shift" view is disputed. In fact, the opposite view is also plausible: According to the "devil shift" argument (Sabatier et al., 1987; Weible et al., 2011) political actors remember their defeats and policy losses more vividly than their victories and policy gains. Thus, they fear their opponents and tend to see them as more powerful than they really are. While there are few "angel shift" mechanisms in our data, there is no "devil shift" either (none of the corresponding coefficients are significant and negative), possibly because the two mechanisms cancel each other out. In any case, our mixed results are in line with the related theoretical controversy (Weible et al., 2011).

By contrast, empirical evidence backs our hypothesis 3. Close collaboration in the network has a consistent effect on reputational power attribution in nine processes (table 1) and seven processes (table 2), respectively. This lends strong support to our claim that actors collaborating closely have a higher probability to consider each other as more powerful than actors not collaborating. Note that the introduction of the centrality variable in model 2 is a crucial test for hypothesis 3 , since powerful actors (i.e. actors with a lot of incoming reputation ties) are often central in collaboration networks (Knoke et al., 1996; Krackhardt, 1990). Therefore, the effect of the collaboration variable on reputation evaluation that we observe in table 1 may simply be an artifact, that is, it may be due to the fact that being powerful and being central are two sides of the same coin. As it turns out, however, the influence of collaboration on reputation attribution is still significant even when controlling for centrality (table 2): While centrality appears as a strong predictor of power assessment, it 
does only slightly affect the impact of collaboration, which remains significant in seven processes out of ten; it is no longer significant only in the processes regarding the law on nuclear energy and the telecommunication act. This gives strong support to our hypothesis 3, as it shows that on top of the strong relation between occupying a central position in the network and reputational power, collaboration also matters. In other words, our results provide support for the view that actors' collaboration affects their mutual evaluation of power, presumably as a result of self-promotion or of perception biases.

Regarding finally hypothesis 4 , table 1 shows that collaboration in parallel decision-making processes has a positive and significant effect in only three processes: The program of budget relief 2003, the constitutional article on the fiscal equalization scheme, and the agreement with the EU on the free movement of persons. Interestingly enough, the fiscal equalization scheme and the program of budget relief 2003 are among the 10 processes that deal with financial aspects of a broad range of different policy domains and, therefore, involve a variety of actors. This may account for the fact that actors that collaborate in other processes consider each other as especially powerful in these two processes. We must nevertheless reject our hypothesis 4 , which is supported in only three cases out of 10 . According to our data, close collaboration in parallel decision-making process, which can be seen as a specific form of multiplexity, does not affect the mutual evaluation of power, except in very specific processes that have a strong trans-sectoral character.

Additional estimations are provided in the appendix, and show that our results are robust to variations in model specifications. Model A1 leaves out the variable measuring collaboration in parallel processes. As a result, collaboration in the process of interest becomes significant in all processes, including that on the program of budget relief 2003. Model A2 includes two variables capturing the intended determinants (formal authority and institutional participation), and takes the third (centrality) out. More importantly, model A3 controls for reputational power (i.e. in-degree centrality). It defines the basic probability that an actor is 
considered by other actors as powerful. Not surprisingly, almost all effects on the node level disappear, but the collaboration effect remains significant in eight networks. Further, model A4 shows that the effects are robust also when we take out the endogenous network mechanisms.

\section{Conclusions}

Reputational power is extensively used in policy analysis. The advantage of the measure lies in its ability to reveal aspects of power that are hidden or hard to measure. However, one needs to be sure that the reputational power measure is valid, i.e. that it measures what it ought to. Accordingly, this paper has attempted to unpack the measure of reputational power and to identify the intended and unintended determinants of actors' mutual assessment of reputational power. It is grounded on the idea that informants are likely to rely on different criteria when evaluating the power of their peers. An actor may be considered as powerful for several - good - reasons: because it has formal authority, because it has access to several institutional arenas, or because it enjoys a central position in the policy network. However, an informant might also consider another actor as powerful for other reasons, such as selfpromotion or misperception. Disentangling the intended and unintended determinants of power attribution is crucial in order to assess the validity of the reputational power measure. To that end, our analysis recognizes the network character of the reputation assessment data between political actors participating in a decision-making process.

Focusing on the likely bias associated with power assessment, we have hypothesized that actors sharing similarities in terms of status or in terms of preferences see each other as more powerful than they are in reality (homophily bias). Additionally, according to our hypothesis regarding the collaboration bias, our interview partners also systematically attribute more power to actors with whom they closely collaborate. Finally, we have also assumed that 
multiplexity as measured by the extent of collaboration in other, parallel decision-making processes also affects power attribution.

Our results are overall reassuring. They show that reputational power essentially measures what it ought to measure. First, our empirical tests have uncovered the existence of the expected intended factors: Formal authority, the intensity of participation in institutional arenas of decision-making processes, and the centrality in the related collaboration network all have - albeit to different extent - a positive effect on power assessment. This is good news, this all the more so since we could obviously not take into account all intended determinants one might think of. That is, besides the intended factors included in our models, there are additional factors that foster actors' power (e.g. their agenda-setting power). Second, and perhaps more importantly, most of the unintended factors that in the researcher's view should not influence power attribution do indeed not show up in our data. Thus, both actor type homophily and preference homophily do hardly influence the attribution of power among actors. Similarly, and still on the safe side mulitplexity, as measured by collaboration in parallel decision-making processes, does not bias the evaluation of power, except in specific decision-making processes with a strong trans-sectoral character.

In that sense, our results highlight the validity of the measure of reputational power. Of course, given the absence of a truly objective measure of power that would serve as a reference point, our results remain to some extent tentative. However, the fact that our analyses are based on a rich collection of network data, include a number of controls and cover a variety of policy domains increases the generalizability of our findings and, therefore, our confidence in the measure of reputational power.

This said, the reputational power measure did not pass all tests, as one of the four hypothesized unintended factors does influence reputation attribution according to our data: Everything else being held constant, actors that collaborate closely in a decision-making process tend to see each other as particularly powerful. This is problematic. While 
collaboration may reduce uncertainty in general, and improve the knowledge of an informant about his/her alters' power in particular, it should not prompt the informant to deem them as powerful.

Scholars resorting to the reputational power measure should therefore be especially attentive to the likely power assessment bias associated with collaboration. They may first attempt to reduce the risk of bias during fieldwork, for instance by alerting interview partners that their assessment of reputational power should be neutral and be made independently from their collaborative ties. Secondly, they may also attempt to overcome the problem at the analysis stage, e.g. by correcting for a possible bias stemming from collaborative ties.

Further, while our data did not enable us to identify whether the unintended effects associated with close collaborative ties originated from deliberate self-promotion or from a perception bias, future research may attempt to develop a research design that allows capturing the difference between both biases. To that end, researchers could go one step further than we do in this paper and elaborate on the difference between direct and indirect self-promotion, or assess whether actors' behavior is in line with their assessment of power. Alternatively, scholars may rely on an interview experiment, in which part of the respondents would be told that the results of the study would be made public and would include actors' names, whereas the other part would be told that the results would remain anonymous. The second variant would presumably lower the risk of deliberate self-promotion. Further, research on reputational power in a political science context could borrow the idea of the issue-specificity of multi-dimensionality from the corporate reputation literature, where for example reputation for financial performance, employee treatment or product quality are distinguished (Walker, 2010; Walsh and Beatty, 2007). Accordingly, reputational power could be subdivided into agenda-setting power, decision-making power and problem-solving power. This would also help to get a finer-grained view of unintended determinants of power assessment and, therefore, to better control for them. 
${ }^{1}$ However, the scope of measuring corporate reputation is somehow different from the scope of measuring reputational power in political studies. While the latter is meant to be a measure that approximates the theoretical concept of political power, the former is a concept on its own that represents a resource to a firm and a competitive advantage on the market.

${ }^{2}$ In line with the definition of power mentioned above, for the purpose of this paper we use "influential" as a synonym of "powerful", and "influence" as a synonym of "power".

${ }^{3}$ Researchers sometimes additionally ask interview partners to indicate powerful actors not present on the predefined list. This is important for reasons of completeness, but obviously distorts the symmetry between informants and actors.

${ }^{4}$ These sums are identical to the in-degree centrality in a network of reputation assessment (Knoke, 1998).

${ }^{5}$ In addition, even if reputational power is inherently subjective, the simple fact that an ego believes that its alter is powerful will have important implications. That is, it will lead ego to behave as if alter was powerful, which in the end will render alter powerful anyway ("self-fulfilling prophecy").

${ }^{6}$ In the Swiss context, it also helps to take into account the "referendum power" of an actor, that is, the fact that an actor can credibly threaten to attack and invalidate a decision by referendum (Fischer, 2005).

${ }^{7}$ By contrast, non-systematic (or random) measurement errors result in variables that have correct values on average and, therefore, do not bias the variables' measurement. However, they may result in biased causal inferences if they affect independent variables. Non-systematic errors are, however, not relevant to our present purpose.

${ }^{8}$ In Switzerland, political actors can call for a popular vote on an issue by collecting 50 '000 signatures in 100 days. This is the so-called optional referendum. The popular vote takes place automatically in the second, compulsory variant of the referendum that applies to any constitutional amendment, and that requires the double majority of the people and of the cantons.

${ }^{9}$ Even if egos adapt their behavior to their perception and, therefore, increase alters' power, the perception bias remains problematic, as the bias does not affect the whole sample, but only egos that share specific characteristics with alters.

${ }^{10}$ The importance of the decision-making processes is based on an expert survey among approximately 80 experts of Swiss politics. Besides the intrinsic interest of studying the most important decision-making 
processes, the fact that the research focuses on these very important processes has the advantage that interview partners could probably remember these processes more easily than other, less important processes.

${ }^{11}$ Most of the interviews were conducted between February and July 2008.

${ }^{12}$ Following the decisional approach, we identified the actors that took part in the different arenas (e.g. expert committees, consultation procedure, parliamentary committees, etc.) of the two decision-making processes. To this list, we added the actors holding an overall strategic position in the Swiss political system (positional approach). Finally, we checked during the first interviews conducted with the administrative actors responsible for the decision-making process that no powerful actor was missing (reputational approach).

${ }^{13}$ Directed (or asymmetric) networks (as opposed to undirected or symmetric networks) are networks in which the relation from actor $i$ to actor $j$ is not automatically equal to the relation from actor $j$ to actor $i$.

${ }^{14}$ Exact wording of the question: "I would like to ask you to indicate which actors were, in your view, very influential in the decision-making process x." For some organizations, more than one representative was interviewed. In these cases, we calculated the average value of their responses and rounded this value to 0 or 1 , as the model is unable to handle valued edges.

${ }^{15}$ ERGMs assume homogeneity of the basic probabilities of each tie - an assumption similar to the assumption in linear regression that a covariate's effect is the same for all observations.

${ }^{16}$ Exact wording of the question: "With which actors did you have convergent or divergent preferences with respect to the decision-making process $\mathrm{x}$ ?"

${ }^{17}$ Exact wording of the question: "Which actors did you strongly collaborate with during the decision-making process x?" Further, we specified that collaboration should be understood as having "frequent contacts".

${ }^{18}$ To some extent, this enables us to avoid a specific problem of endogeneity. It has been shown that actors try to collaborate with others they perceive as powerful (Henry, 2011; Stokman and Zeggelink, 1996). This is exactly the opposite causal relation to the one we want to test. If we observe a statistically significant relation between collaboration and reputation attribution, we can therefore not be sure whether actor a indicates that actor $\mathrm{b}$ is powerful because they collaborate (what we would like to test), or if actor a indicates having collaborated with actor $\mathrm{b}$ because the latter is perceived as powerful (what we would not like to test). If we symmetrize the collaboration data with the minimum method, collaboration relations in our models do not depend only on one actor (which might indicate collaboration because it perceives the other actor as powerful), but are only present if both actors agree on the fact that they collaborated. The collaboration relation can thus not depend on the perceived power. 
${ }^{19}$ As this variable measures collaboration in other domains, endogeneity is not a concern and collaboration does not have to be symmetrized as described above.

${ }^{20}$ Models are estimated with the statnet / ergm packages (Handcock et al., 2010) in R (Rdevelopmentcoreteam, 2011).

${ }^{21}$ We also estimated a joint model for all networks together. Such a model is however unable to converge, which indicates that the data-generating mechanism underlying the 10 networks is very different from network to network. This further supports our approach of studying differences between policy domains.

${ }^{22}$ This parameter controls for the overall probability of a tie in the respective networks (Morris et al., 2008).

${ }^{23}$ In the process on the agreement with the EU on the taxation of savings, political parties had a hard time because of the international and very technical dimension of the project.

${ }^{24}$ As it turns out, the three processes in which peak associations are deemed powerful (the pension scheme reform, the free movement of persons with the EU, and the program of budget relief 2003) are those in which corporatist arrangements were most crucial.

${ }^{25}$ Additional tests, not reported here, show that the impact of participation depends on the formal openness of the decision-making process, as calculated by the proportion of arenas formally open to non-state actors on the total number of arenas of the pre-parliamentary phase: The intensity of participation in institutional arenas matters if the decision-making process is either very open (foreigners, fiscal equalization, education) or very closed (Schengen, telecom). 


\section{References}

Aloiseyoung, P.A., 1993. The Development of Self-Presentation - Self-Promotion in 6-YearOld to 10-Year-Old Children. Social Cognition 11, 201-222.

Bachrach, P., Baratz, M.S., 1962. Two Faces of Power. The American Political Science Review 56, 947-952.

Barnett, M.L., Pollock, T.G., 2012. The Oxford Handbook of Corporate Reputation. Oxford University Press, Oxford.

Bates, S.R., 2010. Re-structuring Power. Polity 42, 352-376.

Cranmer, S.J., Desmarais, B.A., 2011. Inferential Network Analysis with Exponential Random Graph Models. Political Analysis 19, 66-86.

Cronbach, L.J., Meehl, P.E., 1955. Construct Validity in Psychological Tests. Psychological Bulletin 52, 281-302.

Dahl, R.A., 1957. The Concept of Power. Behavioural Science 2, 201-215.

Dahl, R.A., 1961. Who Governs - Democracy and Power in an American City. Yale University Press, New Haven and London.

Emerson, R.M., 1962. Power-Dependence Relations. American Sociological Review 27, 3141.

Fernandez, R.M., Gould, R.V., 1994. A Dilemma of State Power: Brokerage and Influence in the National Health Policy Domain. The American Journal of Sociology 99, 1455-1491.

Fischer, A., 2005. Die Auswirkung der Internationalisierung und Europäisierung auf Schweizer Entscheidungsprozesse. Verlag Rüegger, Zürich/Chur.

Fischer, M., Fischer, A., Sciarini, P., 2009. Power and Conflict in the Swiss Political Elite: An Aggregation of Existing Network Analyses. Swiss Political Science Review 15, 31-62.

Gamson, W.A., 1966. Reputation and Resources in Community Politics. The American Journal of Sociology 72, 121-131.

Goodreau, S.M., Handcock, M.S., Hunter, D.R., Butts, C.T., Morris, M., 2008. A statnet Tutorial. Journal of Statistical Software 24, 1-26.

Goodreau, S.M., Kitts, J.A., Morris, M., 2009. Birds of a feather, or friend of a friend? Using exponential random graph models to investigate adolescent social networks. Demography 46, 103-125.

Granovetter, M., 1985. Economic Action and Social Structure: The Problem of Embeddedness. American Journal of Sociology 91.

Handcock, M.S., Hunter, D.R., Butts, C.T., Goodreau, S.M., Morris, M., 2010. ergm: A Package to Fit, Simulate and Diagnose Exponential-Family Models for Networks. Version 2.2-5.

Heaney, M., 2014. Multiplex Networks and Interest Group Influence Reputation: An Exponential Random Graph Model. Social Networks 36, 66-81.

Henry, A.D., 2011. Ideology, Power, and the Structure of Policy Networks. Policy Studies Journal 39, 361-383.

Ingold, K., 2011. Network Structures within Policy Processes: Coalitions, Power, and Brokerage in Swiss Climate Policy. Policy Studies Journal 39, 435-459.

Katzenstein, P., 1985. Small States in World Markets. Cornell University Press, Cornell.

King, G., Keohane, R.O., Verba, S., 1994. Designing Social Inquiry. Princeton University Press, Princeton, New Jersey.

Kitts, J.A., 2003. Egocentric Bias or Information Management? Selective Disclosure and the Social Roots of Norm Misperception. Social Psychology Quarterly 66, 222-237.

Knoke, D., 1990. Political Networks. The Structural Perspective. Cambridge University Press, Cambridge.

Knoke, D., 1993. Networks of Elite Structure and Decision Making. Sociological Methods \& Research 22, 22-45. 
Knoke, D., 1998. Who steals my purse steals my trash. Journal of Theoretical Politics 10, 507-530.

Knoke, D., Pappi, F.U., Broadbent, J., Tsujinaka, Y., 1996. Comparing Policy Networks Labor Politics in the U.S., Germany, and Japan. Cambridge University Press, Cambridge.

Krackhardt, D., 1990. Assessing the Political Landscape: Structure, Cognition, and Power in Organizations. Administrative Science Quarterly 35, 342-369.

Kriesi, H., 1995. The Political Opportunity Structure of New Social Movements: Its Impact on Their Mobilization, in: Jenkins, J.C., Klandermans, B. (Eds.), The Politics of Social Protest. University of Minnesota Press, Minneapolis, pp. 167-198.

Kriesi, H., Adam, S., Jochum, M., 2006. Comparative analysis of policy networks in Western Europe. Journal of European Public Policy 13, 341-361.

Kriesi, H., Trechsel, A.H., 2008. The Politics of Switzerland. Cambridge University Press, Cambridge.

Laumann, E.O., Knoke, D., 1987. The Organizational State - Social Choice in National Policy Domains. The University of Wisconsin Press, Madison/London.

Laumann, E.O., Pappi, F.U., 1976. Networks of Collective Action: A Perspective on Community Influence Systems. Academic Press, New York.

Leach, W.D., Sabatier, P.A., 2005. To Trust an Adversary: Integrating Rational and Psychological Models of Collaborative Policymaking. American Political Science Review 99, 491-503.

Leifeld, P., Schneider, V., 2012. Information Exchange in Policy Networks. American Journal of Political Science 53, 731-744.

Lukes, S.S., 1974. Power: A Radical View. MacMillan Press, Ltd., London.

Matti, S., Sandström, A., 2011. The Rationale Determining Advocacy Coalitions: Examining Coordination Networks and Corresponding Beliefs. Policy Studies Journal 39, 385-410.

Molleman, E., Emans, B., Turusbekova, N., 2012. How to control self-promotion among performance-oriented employees The roles of task clarity and personalized responsibility. Personnel Review 41, 88-105.

Morris, M., Handcock, M.S., Hunter, D.R., 2008. Specification of Exponential-Family Random Graph Models: Terms and Computational Aspects. Journal of Statistical Software 24, 1-24.

Pfeffer, J., Fong, C.T., Cialdini, R.B., Portnoy, R.R., 2006. Overcoming the self-promotion dilemma: Interpersonal attraction and extra help as a consequence of who sings one's praises. Personality and Social Psychology Bulletin 32, 1362-1374.

Ponzi, L.J., Fombrun, C.J., Gardberg, N.A., 2011. RepTrak TM Pulse: Conceptualizing and Validating a Short-Form Measure of Corporate Reputation. Corporate Reputation Review 14, 15-35.

Proost, K., Schreurs, B., De Witte, K., Derous, E., 2010. Ingratiation and Self-Promotion in the Selection Interview: The Effects of Using Single Tactics or a Combination of Tactics on Interviewer Judgments. Journal of Applied Social Psychology 40, 21552169.

Rdevelopmentcoreteam, 2011. R: A language and environment for statistical computing. R Foundation for Statistical Computing, Vienna, Austria.

Robins, G., Pattison, P., Kalish, Y., Lusher, D., 2007. An introduction to exponential random graph $\left(\mathrm{p}^{*}\right)$ models for social networks. Social Networks 29, 173-191.

Sabatier, P., Hunter, S., Mclaughlin, S., 1987. The Devil Shift: Perceptions and Misperceptions of Opponents. Political Research Quarterly 40, 449-476.

Scholz, J.T., Berardo, R., Kile, B., 2008. Do Networks Solve Collective Action Problems? Credibility, Search, and Collaboration. The Journal of Politics 70, 393-406. 
Sciarini, P., 2014. Eppure si muove: The changing nature of the Swiss consensus democracy. Journal of European Public Policy 21, 116-132.

Sciarini, P., Fischer, A., Nicolet, S., 2004. How Europe hits home: evidence from the Swiss case. Journal of European Public Policy 11, 353-378.

Scott, J., 1994. Power - Critical Concepts. Routledge, London.

Stokman, F.N., Zeggelink, E.P.H., 1996. Is Politics Power or Policy Oriented? A Comparative Analysis of Dynamic Access Models in Policy Networks. Journal of Mathematical Sociology 21, 77-111.

Tal-Or, N., 2010. Direct and indirect self-promotion in the eyes of the perceivers. Social Influence 5, 87-100.

Walker, K., 2010. A Systematic Review of the Corporate Reputation Literature: Definition, Measurement, and Theory. Corporate Reputation Review 12, 357-387.

Walsh, G., Beatty, S., 2007. Customer-based corporate reputation of a service firm: scale development and validation. Journal of the Academy of Marketing Science 35, 127-143.

Wasserman, S., Pattison, P., 1996. Logit Models and Logistic Regressions for Social Networks: An Introduction to Markov Graphs and p*. Psychometrika 61, 401-425.

Wasserman, S., Robins, G., 2005. An Introduction to Random Graphs, Dependence Graphs, and $\mathrm{p}^{*}$, in: Carrington, P.J., Scott, J., Wasserman, S. (Eds.), Models and Methods in Social Network Analysis. Cambridge University Press, Cambridge, pp. 148-161.

Watling, D., Banerjee, R., 2007. Children's differentiation between ingratiation and selfpromotion. Social Development 16, 758-776.

Weible, C.M., Sabatier, P.A., 2005. Comparing Policy Networks: Marine Protected Areas in California. The Policy Studies Journal 33, 181-201.

Weible, C.M., Siddiki, S.N., Pierce, J.J., 2011. Foes to Friends: Changing Contexts and Changing Intergroup Perceptions. Journal of Comparative Policy Analysis: Research and Practice 13, 499-525.

Weiss, U., 1996. Macht, in: Nohlen, D., Schultze, R.-O. (Eds.), Lexikon der Politik Politische Theorien. Büchergilde Gutenberg, Frankfurst am Main.

Wolfinger, R.E., 1960. Reputation and Reality in the Study of "Community Power". American Sociological Review 25, 636-644. 
Tables

Table 1

\begin{tabular}{|c|c|c|c|c|c|c|c|c|c|c|}
\hline & $\frac{\frac{\grave{d}}{\tilde{J}}}{\stackrel{\Xi}{z}}$ & 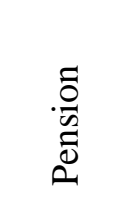 & 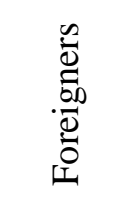 & $\begin{array}{l}\vec{D} \\
\stackrel{6}{0} \\
\vec{D}\end{array}$ & 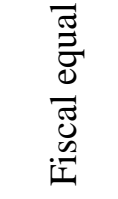 & 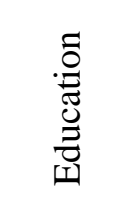 & 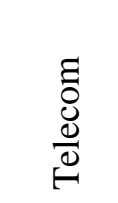 & 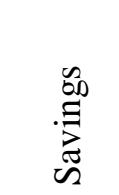 & $\begin{array}{l}0 \\
0 \\
0 \\
\vdots \\
0 \\
0\end{array}$ & $\begin{array}{l}\bar{D} \\
00 \\
\bar{D} \\
\bar{U} \\
\mathscr{n}\end{array}$ \\
\hline Edges & $\begin{array}{c}-2.42 \\
(1.65)\end{array}$ & $\begin{array}{l}-3.42 \\
(2.57)\end{array}$ & $\begin{array}{l}-5.01 \\
(1.36)\end{array}$ & $\begin{array}{l}-3.81 \\
(1.04)\end{array}$ & $\begin{array}{l}-5.14 \\
(4.61)\end{array}$ & $\begin{array}{l}-2.34 \\
(2.19)\end{array}$ & $\begin{array}{l}-2.75 \\
(2.43)\end{array}$ & $\begin{array}{c}-3.84 \\
(1.01)\end{array}$ & $\begin{array}{l}-4.85 \\
(1.59)\end{array}$ & $\begin{array}{c}-1.41 \\
(1.32)\end{array}$ \\
\hline Reciprocity & $\begin{array}{c}0.51 \\
(0.26)\end{array}$ & $\begin{array}{c}0.16 \\
(0.31)\end{array}$ & $\begin{array}{c}0.61 \\
(0.35)\end{array}$ & $\begin{array}{c}0.18 \\
(0.32)\end{array}$ & $\begin{array}{l}-0.17 \\
(0.33)\end{array}$ & $\begin{array}{l}-0.75 \\
(0.36)\end{array}$ & $\begin{array}{l}-0.48 \\
(0.31)\end{array}$ & $\begin{array}{l}-0.07 \\
(0.41)\end{array}$ & $\begin{array}{l}-0.39 \\
(0.29)\end{array}$ & $\begin{array}{c}-0.38 \\
(0.26)\end{array}$ \\
\hline GWDSP & $\begin{array}{c}\mathbf{- 0 . 2 4} \\
(\mathbf{0 . 0 9})\end{array}$ & $\begin{array}{c}0.17 \\
(0.67)\end{array}$ & $\begin{array}{c}-\mathbf{- 0 . 2 2} \\
(0.09)\end{array}$ & $\begin{array}{l}-0.25 \\
(0.05)\end{array}$ & $\begin{array}{c}\mathbf{- 0 . 1 8} \\
(\mathbf{0 . 0 8})\end{array}$ & $\begin{array}{l}-0.28 \\
(0.15)\end{array}$ & $\begin{array}{c}-\mathbf{- 0 . 2 6} \\
(\mathbf{0 . 0 8})\end{array}$ & $\begin{array}{c}\mathbf{- 0 . 3 3} \\
(\mathbf{0 . 0 8})\end{array}$ & $\begin{array}{c}-\mathbf{- 0 . 2 3} \\
(\mathbf{0 . 0 5})\end{array}$ & $\begin{array}{c}-0.18 \\
(0.08)\end{array}$ \\
\hline GWESP & $\begin{array}{c}-0.53 \\
(1.09)\end{array}$ & $\begin{array}{l}-1.93 \\
(1.76)\end{array}$ & $\begin{array}{c}0.59 \\
(0.95)\end{array}$ & $\begin{array}{l}-0.20 \\
(0.60)\end{array}$ & $\begin{array}{c}1.43 \\
(3.95)\end{array}$ & $\begin{array}{l}-1.24 \\
(1.21)\end{array}$ & $\begin{array}{c}0.20 \\
(1.61)\end{array}$ & $\begin{array}{c}0.73 \\
(0.57)\end{array}$ & $\begin{array}{c}0.57 \\
(0.97)\end{array}$ & $\begin{array}{l}-1.07 \\
(0.68)\end{array}$ \\
\hline Reputation outdegree & $\begin{array}{c}0.19 \\
(\mathbf{0 . 0 3})\end{array}$ & $\begin{array}{c}0.32 \\
(0.06)\end{array}$ & $\begin{array}{c}0.33 \\
(0.06)\end{array}$ & $\begin{array}{c}0.27 \\
(\mathbf{0 . 0 4})\end{array}$ & $\begin{array}{c}0.21 \\
(\mathbf{0 . 0 3})\end{array}$ & $\begin{array}{c}0.29 \\
(0.08)\end{array}$ & $\begin{array}{c}0.24 \\
(0.05)\end{array}$ & $\begin{array}{c}0.22 \\
(0.06)\end{array}$ & $\begin{array}{c}0.24 \\
(0.04)\end{array}$ & $\begin{array}{c}0.17 \\
(0.04)\end{array}$ \\
\hline Reputation indegree & & & & & & & & & & \\
\hline Leading agency & $\begin{array}{c}2.80 \\
(0.79)\end{array}$ & $\begin{array}{c}5.67 \\
(1.10)\end{array}$ & $\begin{array}{c}1.26 \\
(0.43)\end{array}$ & $\begin{array}{c}4.96 \\
(0.73)\end{array}$ & $\begin{array}{c}2.40 \\
(0.38)\end{array}$ & $\begin{array}{c}2.04 \\
(0.48)\end{array}$ & $\begin{array}{c}4.56 \\
(1.56)\end{array}$ & $\begin{array}{c}2.26 \\
(0.46)\end{array}$ & $\begin{array}{c}1.68 \\
(0.36)\end{array}$ & $\begin{array}{c}1.28 \\
(0.30)\end{array}$ \\
\hline Government party & $\begin{array}{c}1.45 \\
(0.34)\end{array}$ & $\begin{array}{c}\mathbf{3 . 0 2} \\
(\mathbf{0 . 4 4 )}\end{array}$ & $\begin{array}{c}3.64 \\
(\mathbf{0 . 4 7})\end{array}$ & $\begin{array}{c}2.26 \\
(0.40)\end{array}$ & $\begin{array}{c}1.61 \\
(0.36)\end{array}$ & $\begin{array}{c}1.71 \\
(0.41)\end{array}$ & $\begin{array}{c}1.74 \\
(0.40)\end{array}$ & $\begin{array}{c}0.57 \\
(0.39)\end{array}$ & $\begin{array}{c}2.82 \\
(0.41)\end{array}$ & $\begin{array}{c}1.50 \\
(\mathbf{0 . 3 1})\end{array}$ \\
\hline Peak association & $\begin{array}{c}0.10 \\
(0.32)\end{array}$ & $\begin{array}{c}2.42 \\
(0.40)\end{array}$ & $\begin{array}{c}0.38 \\
(0.30)\end{array}$ & $\begin{array}{c}\mathbf{0 . 8 6} \\
(\mathbf{0 . 2 9})\end{array}$ & $\begin{array}{l}-0.43 \\
(0.46)\end{array}$ & $\begin{array}{c}0.44 \\
(' 0.42)\end{array}$ & $\begin{array}{l}-0.07 \\
(0.40)\end{array}$ & $\begin{array}{c}-0.42 \\
(0.39)\end{array}$ & $\begin{array}{c}1.92 \\
(\mathbf{0 . 3 5})\end{array}$ & $\begin{array}{c}0.21 \\
(0.34)\end{array}$ \\
\hline Participation & & & & & & & & & & \\
\hline Degree centrality & & & & & & & & & & \\
\hline Actor type homophily & $\begin{array}{c}0.37 \\
(0.21)\end{array}$ & $\begin{array}{c}0.48 \\
(0.31)\end{array}$ & $\begin{array}{c}0.01 \\
(0.30)\end{array}$ & $\begin{array}{l}-0.27 \\
(0.26)\end{array}$ & $\begin{array}{c}0.14 \\
(0.28)\end{array}$ & $\begin{array}{c}0.10 \\
(0.35)\end{array}$ & $\begin{array}{l}-0.16 \\
(0.30)\end{array}$ & $\begin{array}{c}0.39 \\
(0.35)\end{array}$ & $\begin{array}{c}0.20 \\
(0.26)\end{array}$ & $\begin{array}{c}-0.04 \\
(0.23)\end{array}$ \\
\hline Preference homophily & $\begin{array}{c}-0.13 \\
(0.18)\end{array}$ & $\begin{array}{l}-0.22 \\
(0.27)\end{array}$ & $\begin{array}{c}0.21 \\
(0.26)\end{array}$ & $\begin{array}{c}0.30 \\
(0.21)\end{array}$ & $\begin{array}{c}0.45 \\
(0.28)\end{array}$ & $\begin{array}{c}1.05 \\
(0.31)\end{array}$ & $\begin{array}{c}0.18 \\
(0.20)\end{array}$ & $\begin{array}{c}1.46 \\
(0.30)\end{array}$ & $\begin{array}{l}-0.01 \\
(0.19)\end{array}$ & $\begin{array}{c}-0.19 \\
(0.18)\end{array}$ \\
\hline Collaboration & $\begin{array}{c}1.10 \\
(\mathbf{0 . 3 2})\end{array}$ & $\begin{array}{c}1.22 \\
(0.42)\end{array}$ & $\begin{array}{c}1.67 \\
(0.46)\end{array}$ & $\begin{array}{c}0.50 \\
(0.36)\end{array}$ & $\begin{array}{c}1.84 \\
(0.44)\end{array}$ & $\begin{array}{c}2.31 \\
(0.42)\end{array}$ & $\begin{array}{c}1.29 \\
(0.32)\end{array}$ & $\begin{array}{c}1.68 \\
(0.46)\end{array}$ & $\begin{array}{c}1.25 \\
(\mathbf{0 . 3 4})\end{array}$ & $\begin{array}{c}2.30 \\
(0.36)\end{array}$ \\
\hline Parallel collaboration & $\begin{array}{c}-0.08 \\
(0.07)\end{array}$ & $\begin{array}{c}0.17 \\
(0.11)\end{array}$ & $\begin{array}{c}-0.17 \\
(0.09)\end{array}$ & $\begin{array}{c}0.19 \\
(0.08)\end{array}$ & $\begin{array}{c}0.35 \\
(\mathbf{0 . 1 1})\end{array}$ & $\begin{array}{c}-0.15 \\
(0.09)\end{array}$ & $\begin{array}{c}-0.00 \\
(0.09)\end{array}$ & $\begin{array}{c}0.08 \\
(0.08)\end{array}$ & $\begin{array}{c}0.18 \\
(0.09)\end{array}$ & $\begin{array}{c}-0.02 \\
(0.09)\end{array}$ \\
\hline AIC & 598.9 & 430.8 & 376.6 & 502.5 & 504.2 & 389.8 & 472.0 & 293.3 & 573.0 & 696.5 \\
\hline BIC & 650.7 & 481.5 & 423.9 & 555.3 & 555.9 & 437.1 & 521.6 & 339.3 & 626.7 & 750.3 \\
\hline
\end{tabular}

Standard errors appear in brackets. Figures in bold indicate significance at the 0.05 level. 


\begin{tabular}{|c|c|c|c|c|c|c|c|c|c|c|}
\hline & 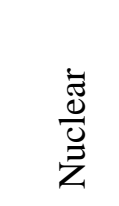 & $\begin{array}{l}\text {.0 } \\
0 \\
0 \\
0\end{array}$ & 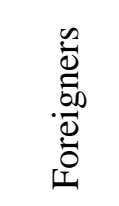 & $\begin{array}{l}\vec{\Phi} \\
\vec{\infty} \\
\vec{D} \\
\vec{D}\end{array}$ & 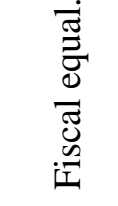 & 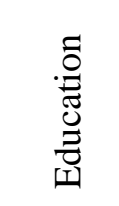 & 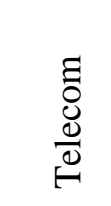 & 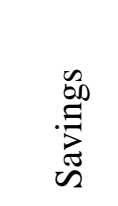 & $\begin{array}{l}\tilde{0} \\
0 \\
\overline{0} \\
0\end{array}$ & 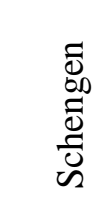 \\
\hline Edges & $\begin{array}{c}-3.73 \\
(1.74)\end{array}$ & $\begin{array}{c}-4.06 \\
(2.62)\end{array}$ & $\begin{array}{l}-7.47 \\
(1.62)\end{array}$ & $\begin{array}{l}-3.86 \\
(1.53)\end{array}$ & $\begin{array}{l}-7.74 \\
(6.54)\end{array}$ & $\begin{array}{l}-6.36 \\
(2.54)\end{array}$ & $\begin{array}{l}-6.02 \\
(2.80)\end{array}$ & $\begin{array}{c}-6.00 \\
(1.25)\end{array}$ & $\begin{array}{c}-6.88 \\
(1.79)\end{array}$ & $\begin{array}{c}-2.82 \\
(1.48)\end{array}$ \\
\hline Reciprocity & $\begin{array}{c}0.51 \\
(0.28)\end{array}$ & $\begin{array}{c}0.13 \\
(0.32)\end{array}$ & $\begin{array}{c}\mathbf{0 . 8 9} \\
(\mathbf{0 . 3 8})\end{array}$ & $\begin{array}{c}0.18 \\
(0.30)\end{array}$ & $\begin{array}{c}0.23 \\
(0.35)\end{array}$ & $\begin{array}{l}-0.70 \\
(0.38)\end{array}$ & $\begin{array}{c}0.23 \\
(0.37)\end{array}$ & $\begin{array}{c}-0.34 \\
(0.47)\end{array}$ & $\begin{array}{c}-0.44 \\
(0.30)\end{array}$ & $\begin{array}{c}-0.41 \\
(0.26)\end{array}$ \\
\hline GWDSP & $\begin{array}{c}-\mathbf{- 0 . 1 8} \\
(\mathbf{0 . 0 8})\end{array}$ & $\begin{array}{c}0.31 \\
(0.68)\end{array}$ & $\begin{array}{l}-0.09 \\
(0.09)\end{array}$ & $\begin{array}{l}\mathbf{- 0 . 2 5} \\
(\mathbf{0 . 0 5})\end{array}$ & $\begin{array}{l}-0.10 \\
(0.07)\end{array}$ & $\begin{array}{c}0.05 \\
(0.18)\end{array}$ & $\begin{array}{c}-0.19 \\
(0.12)\end{array}$ & $\begin{array}{l}-0.16 \\
(0.09)\end{array}$ & $\begin{array}{c}-0.13 \\
(0.06)\end{array}$ & $\begin{array}{c}-0.16 \\
(0.08)\end{array}$ \\
\hline GWESP & $\begin{array}{c}-0.55 \\
(1.03)\end{array}$ & $\begin{array}{c}-2.05 \\
(1.76)\end{array}$ & $\begin{array}{c}0.34 \\
(0.90)\end{array}$ & $\begin{array}{l}-0.19 \\
(0.57)\end{array}$ & $\begin{array}{c}2.00 \\
(5.43)\end{array}$ & $\begin{array}{c}-0.95 \\
(1.29)\end{array}$ & $\begin{array}{c}-0.22 \\
(1.36)\end{array}$ & $\begin{array}{c}0.50 \\
(0.58)\end{array}$ & $\begin{array}{c}0.42 \\
(0.80)\end{array}$ & $\begin{array}{l}-1.09 \\
(0.71)\end{array}$ \\
\hline Reput & $\begin{array}{c}0.23 \\
(\mathbf{0 . 0 4})\end{array}$ & $\begin{array}{c}0.33 \\
(\mathbf{0 . 0 6})\end{array}$ & $\begin{array}{c}0.38 \\
(0.07)\end{array}$ & $\begin{array}{c}0.27 \\
(0.04)\end{array}$ & $\begin{array}{c}0.24 \\
(0.04)\end{array}$ & $\begin{array}{c}0.39 \\
(0.08)\end{array}$ & $\begin{array}{c}0.30 \\
(0.06)\end{array}$ & $\begin{array}{c}\mathbf{0 . 3 3} \\
(\mathbf{0 . 0 7})\end{array}$ & $\begin{array}{c}0.29 \\
(0.05)\end{array}$ & $\begin{array}{c}0.20 \\
(0.04)\end{array}$ \\
\hline Reputation indegre & & & & & & & & & & \\
\hline Lead & $\begin{array}{c}1.20 \\
(1.02)\end{array}$ & $\begin{array}{c}4.64 \\
(1.15)\end{array}$ & $\begin{array}{c}0.45 \\
(0.55)\end{array}$ & $\begin{array}{c}4.80 \\
(1.77)\end{array}$ & $\begin{array}{l}-1.12 \\
(0.65)\end{array}$ & $\begin{array}{c}1.50 \\
(0.66)\end{array}$ & $\begin{array}{c}3.82 \\
(1.47)\end{array}$ & $\begin{array}{c}1.62 \\
(0.52)\end{array}$ & $\begin{array}{l}-1.29 \\
(0.91)\end{array}$ & $\begin{array}{c}0.60 \\
(0.32)\end{array}$ \\
\hline Gove & $\begin{array}{c}0.84 \\
(0.43)\end{array}$ & $\begin{array}{c}2.11 \\
(0.54)\end{array}$ & $\begin{array}{c}2.44 \\
(0.55)\end{array}$ & $\begin{array}{c}2.18 \\
(0.92)\end{array}$ & $\begin{array}{c}\mathbf{0 . 8 0} \\
(\mathbf{0 . 3 5})\end{array}$ & $\begin{array}{c}0.20 \\
(0.53)\end{array}$ & $\begin{array}{c}0.80 \\
(0.44)\end{array}$ & $\begin{array}{c}0.99 \\
(0.47)\end{array}$ & $\begin{array}{c}1.90 \\
(0.45)\end{array}$ & $\begin{array}{c}0.62 \\
(0.40)\end{array}$ \\
\hline Peal & $\begin{array}{c}-0.42 \\
(0.34)\end{array}$ & $\begin{array}{c}1.96 \\
(0.41)\end{array}$ & $\begin{array}{l}-0.30 \\
(0.37)\end{array}$ & $\begin{array}{c}0.83 \\
(0.32)\end{array}$ & $\begin{array}{c}-0.74 \\
(0.48)\end{array}$ & $\begin{array}{l}-0.26 \\
(0.49)\end{array}$ & $\begin{array}{c}0.27 \\
(0.43)\end{array}$ & $\begin{array}{l}-0.09 \\
(0.56)\end{array}$ & $\begin{array}{c}0.98 \\
(0.39)\end{array}$ & $\begin{array}{c}0.63 \\
(0.40)\end{array}$ \\
\hline Par & $\begin{array}{c}-0.33 \\
(1.16)\end{array}$ & $\begin{array}{c}0.74 \\
(0.76)\end{array}$ & $\begin{array}{c}4.45 \\
(1.17)\end{array}$ & $\begin{array}{c}0.07 \\
(1.42)\end{array}$ & $\begin{array}{c}1.67 \\
(0.60)\end{array}$ & $\begin{array}{c}2.22 \\
(0.87)\end{array}$ & $\begin{array}{c}3.19 \\
(0.93)\end{array}$ & $\begin{array}{c}0.30 \\
(0.68)\end{array}$ & $\begin{array}{c}1.12 \\
(1.21)\end{array}$ & $\begin{array}{c}1.29 \\
(0.63)\end{array}$ \\
\hline DegI & $\begin{array}{c}7.64 \\
(1.54)\end{array}$ & $\begin{array}{c}3.49 \\
(1.69)\end{array}$ & $\begin{array}{c}4.87 \\
(1.75)\end{array}$ & $\begin{array}{c}0.26 \\
(2.13)\end{array}$ & $\begin{array}{c}9.40 \\
(1.88)\end{array}$ & $\begin{array}{c}6.49 \\
(1.50)\end{array}$ & $\begin{array}{c}4.31 \\
(1.07)\end{array}$ & $\begin{array}{c}6.28 \\
(1.55)\end{array}$ & $\begin{array}{c}7.26 \\
(1.56)\end{array}$ & $\begin{array}{c}4.01 \\
(0.94)\end{array}$ \\
\hline Actor & $\begin{array}{c}0.29 \\
(0.23)\end{array}$ & $\begin{array}{c}0.51 \\
(0.32)\end{array}$ & $\begin{array}{c}0.18 \\
(0.32)\end{array}$ & $\begin{array}{l}-0.27 \\
(0.27)\end{array}$ & $\begin{array}{c}0.38 \\
(0.30)\end{array}$ & $\begin{array}{c}0.10 \\
(0.36)\end{array}$ & $\begin{array}{c}-0.09 \\
(0.34)\end{array}$ & $\begin{array}{c}0.59 \\
(0.39)\end{array}$ & $\begin{array}{c}0.39 \\
(0.28)\end{array}$ & $\begin{array}{c}0.02 \\
(0.25)\end{array}$ \\
\hline Prefere & $\begin{array}{c}0.14 \\
(0.20)\end{array}$ & $\begin{array}{c}-0.24 \\
(0.27)\end{array}$ & $\begin{array}{c}0.23 \\
(0.28)\end{array}$ & $\begin{array}{c}0.31 \\
(0.21)\end{array}$ & $\begin{array}{c}0.65 \\
(0.29)\end{array}$ & $\begin{array}{c}0.95 \\
(0.34)\end{array}$ & $\begin{array}{c}-0.01 \\
(0.21)\end{array}$ & $\begin{array}{c}1.42 \\
(0.33)\end{array}$ & $\begin{array}{c}-0.04 \\
(0.20)\end{array}$ & $\begin{array}{l}-0.19 \\
(0.19)\end{array}$ \\
\hline Collabo & $\begin{array}{c}0.41 \\
(0.36)\end{array}$ & $\begin{array}{c}1.04 \\
(0.45)\end{array}$ & $\begin{array}{c}1.30 \\
(0.51)\end{array}$ & $\begin{array}{c}0.47 \\
(0.41)\end{array}$ & $\begin{array}{c}0.96 \\
(0.45)\end{array}$ & $\begin{array}{c}1.79 \\
(0.44)\end{array}$ & $\begin{array}{c}0.62 \\
(0.34)\end{array}$ & $\begin{array}{c}1.22 \\
(0.51)\end{array}$ & $\begin{array}{c}0.91 \\
(0.36)\end{array}$ & $\begin{array}{c}1.89 \\
(0.37)\end{array}$ \\
\hline Paral & $\begin{array}{c}-0.06 \\
(0.07)\end{array}$ & $\begin{array}{c}0.16 \\
(0.11) \\
\end{array}$ & $\begin{array}{c}-0.21 \\
(0.09) \\
\end{array}$ & $\begin{array}{c}0.19 \\
(0.08) \\
\end{array}$ & $\begin{array}{c}0.42 \\
(0.12) \\
\end{array}$ & $\begin{array}{c}-0.12 \\
(0.09) \\
\end{array}$ & $\begin{array}{c}-0.02 \\
(0.10)\end{array}$ & $\begin{array}{c}0.07 \\
(0.09) \\
\end{array}$ & $\begin{array}{c}0.18 \\
(0.09) \\
\end{array}$ & $\begin{array}{c}0.00 \\
(0.09) \\
\end{array}$ \\
\hline & & & & 300.0 & & & & & & 659.2 \\
\hline & 619.3 & 486.6 & 402.6 & 568 & 538.3 & 402.3 & 475.2 & 326.8 & 598.4 & 721.9 \\
\hline
\end{tabular}

Standard errors appear in brackets. Figures in bold indicate significance at the 0.05 level. 


\section{Appendix}

\section{Model A1}

\begin{tabular}{|c|c|c|c|c|c|c|c|c|c|c|}
\hline & 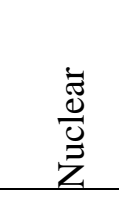 & $\begin{array}{l}\frac{0}{0} \\
\frac{0}{0} \\
0 \\
\text { 2. }\end{array}$ & 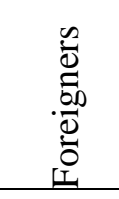 & 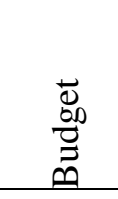 & 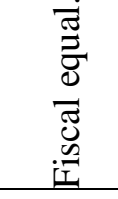 & 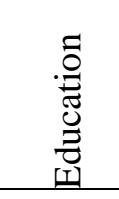 & 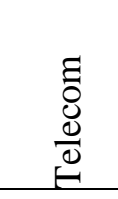 & 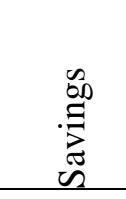 & 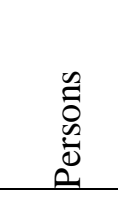 & $\begin{array}{l}\tilde{D} \\
\bar{D} \\
\overline{0} \\
\overline{0} \\
\tilde{D}\end{array}$ \\
\hline Edges & $\begin{array}{c}-2.40 \\
(1.67)\end{array}$ & $\begin{array}{c}-3.31 \\
(2.61)\end{array}$ & $\begin{array}{l}-4.89 \\
(1.42)\end{array}$ & $\begin{array}{c}-3.89 \\
(1.26)\end{array}$ & $\begin{array}{c}-5.34 \\
(5.89)\end{array}$ & $\begin{array}{l}-1.68 \\
(2.19)\end{array}$ & $\begin{array}{c}-2.77 \\
(2.43)\end{array}$ & $\begin{array}{c}-3.87 \\
(\mathbf{1 . 0 8})\end{array}$ & $\begin{array}{c}-4.89 \\
(1.75)\end{array}$ & $\begin{array}{c}-1.40 \\
(1.37)\end{array}$ \\
\hline Reciprocity & $\begin{array}{c}0.51 \\
(0.27)\end{array}$ & $\begin{array}{c}0.24 \\
(0.31)\end{array}$ & $\begin{array}{c}0.48 \\
(0.34)\end{array}$ & $\begin{array}{c}0.26 \\
(0.31)\end{array}$ & $\begin{array}{c}0.30 \\
(0.31)\end{array}$ & $\begin{array}{c}-0.68 \\
(0.35)\end{array}$ & $\begin{array}{c}-0.48 \\
(0.30)\end{array}$ & $\begin{array}{l}-0.07 \\
(0.40)\end{array}$ & $\begin{array}{c}-0.26 \\
(0.28)\end{array}$ & $\begin{array}{l}-0.39 \\
(0.26)\end{array}$ \\
\hline GWDSP & $\begin{array}{c}-\mathbf{- 0 . 2 4} \\
(\mathbf{0 . 0 8})\end{array}$ & $\begin{array}{c}0.16 \\
(0.67)\end{array}$ & $\begin{array}{l}\mathbf{- 0 . 2 4} \\
(\mathbf{0 . 0 9})\end{array}$ & $\begin{array}{l}\mathbf{- 0 . 2 5} \\
(\mathbf{0 . 0 5})\end{array}$ & $\begin{array}{l}-0.11 \\
(0.09)\end{array}$ & $\begin{array}{c}\mathbf{- 0 . 3 1} \\
(\mathbf{0 . 1 4})\end{array}$ & $\begin{array}{c}\mathbf{- 0 . 2 6} \\
(\mathbf{0 . 0 8})\end{array}$ & $\begin{array}{c}\mathbf{- 0 . 3 4} \\
(\mathbf{0 . 0 8})\end{array}$ & $\begin{array}{c}\mathbf{- 0 . 2 4} \\
(\mathbf{0 . 0 5})\end{array}$ & $\begin{array}{c}\mathbf{- 0 . 1 9} \\
(\mathbf{0 . 0 8})\end{array}$ \\
\hline GWESP & $\begin{array}{c}-0.53 \\
(1.09)\end{array}$ & $\begin{array}{c}-1.89 \\
(1.79)\end{array}$ & $\begin{array}{c}0.49 \\
(0.96)\end{array}$ & $\begin{array}{l}-0.17 \\
(0.66)\end{array}$ & $\begin{array}{c}2.01 \\
(5.07)\end{array}$ & $\begin{array}{l}-1.29 \\
(1.18)\end{array}$ & $\begin{array}{c}0.20 \\
(1.62)\end{array}$ & $\begin{array}{c}0.73 \\
(' 0.60)\end{array}$ & $\begin{array}{c}0.55 \\
(1.04)\end{array}$ & $\begin{array}{l}-1.06 \\
(0.71)\end{array}$ \\
\hline Reputation outdegree & $\begin{array}{c}0.19 \\
(0.03)\end{array}$ & $\begin{array}{c}0.31 \\
(0.06)\end{array}$ & $\begin{array}{c}0.33 \\
(0.06)\end{array}$ & $\begin{array}{c}0.28 \\
(0.05)\end{array}$ & $\begin{array}{c}\text { 0.20 } \\
(\mathbf{0 . 0 3})\end{array}$ & $\begin{array}{c}0.25 \\
(0.08)\end{array}$ & $\begin{array}{c}0.24 \\
(0.05)\end{array}$ & $\begin{array}{c}0.23 \\
(0.06)\end{array}$ & $\begin{array}{c}0.24 \\
(0.05)\end{array}$ & $\begin{array}{c}0.17 \\
(\mathbf{0 . 0 4})\end{array}$ \\
\hline Reputat & & & & & & & & & & \\
\hline Leading & $\begin{array}{c}2.81 \\
(\mathbf{0 . 7 7})\end{array}$ & $\begin{array}{c}5.65 \\
(1.13)\end{array}$ & $\begin{array}{c}1.19 \\
(0.43)\end{array}$ & $\begin{array}{c}5.01 \\
(0.84)\end{array}$ & $\begin{array}{c}0.97 \\
(\mathbf{0 . 4 5})\end{array}$ & $\begin{array}{c}0.98 \\
(\mathbf{0 . 4 8})\end{array}$ & $\begin{array}{c}4.55 \\
(1.53)\end{array}$ & $\begin{array}{c}2.27 \\
(\mathbf{0 . 4 8})\end{array}$ & $\begin{array}{c}1.70 \\
(\mathbf{0 . 4 0})\end{array}$ & $\begin{array}{c}1.27 \\
(0.29)\end{array}$ \\
\hline Government party & $\begin{array}{c}1.33 \\
(\mathbf{0 . 3 1})\end{array}$ & $\begin{array}{c}3.05 \\
(0.45)\end{array}$ & $\begin{array}{c}3.38 \\
(0.46)\end{array}$ & $\begin{array}{c}2.40 \\
(\mathbf{0 . 4 5})\end{array}$ & $\begin{array}{c}1.27 \\
(0.32)\end{array}$ & $\begin{array}{c}1.36 \\
(0.37)\end{array}$ & $\begin{array}{c}1.74 \\
(0.38)\end{array}$ & $\begin{array}{c}0.69 \\
(0.37)\end{array}$ & $\begin{array}{c}2.94 \\
(0.43)\end{array}$ & $\begin{array}{c}1.48 \\
(0.29)\end{array}$ \\
\hline Peak association & $\begin{array}{c}0.03 \\
(0.31)\end{array}$ & $\begin{array}{c}2.48 \\
(0.40)\end{array}$ & $\begin{array}{c}0.29 \\
(0.30)\end{array}$ & $\begin{array}{c}0.95 \\
(\mathbf{0 . 3 0})\end{array}$ & $\begin{array}{l}-0.54 \\
(0.42)\end{array}$ & $\begin{array}{c}0.17 \\
(0.40)\end{array}$ & $\begin{array}{c}0.08 \\
(0.39)\end{array}$ & $\begin{array}{c}-0.33 \\
(0.38)\end{array}$ & $\begin{array}{c}1.99 \\
(0.37)\end{array}$ & $\begin{array}{c}0.18 \\
(0.34)\end{array}$ \\
\hline
\end{tabular}

Degree centrality

$\begin{array}{lcccccccccc}\text { Actor type homophily } & 0.34 & 0.49 & 0.01 & -0.25 & 0.26 & 0.10 & -0.15 & 0.44 & 0.22 & -0.05 \\ & (0.22) & (0.31) & (0.30) & (0.26) & (0.26) & (0.33) & (0.30) & (0.34) & (0.26) & (0.24) \\ \text { Preference homophily } & -0.15 & -0.17 & 0.14 & 0.36 & \mathbf{0 . 5 8} & \mathbf{0 . 8 8} & -0.18 & \mathbf{1 . 4 4} & 0.04 & -0.19 \\ & (0.17) & (0.26) & (0.25) & (0.21) & (\mathbf{0 . 2 5}) & (\mathbf{0 . 3 0}) & (0.20) & (\mathbf{0 . 3 1}) & (0.19) & (0.18) \\ \text { Collaboration } & \mathbf{1 . 0 4} & \mathbf{1 . 2 9} & \mathbf{1 . 5 9} & \mathbf{0 . 7 1} & \mathbf{1 . 7 4} & \mathbf{2 . 2 6} & \mathbf{1 . 2 8} & \mathbf{1 . 7 1} & \mathbf{1 . 3 4} & \mathbf{2 . 2 8} \\ & \mathbf{( 0 . 3 1 )} & \mathbf{( 0 . 4 2}) & (\mathbf{0 . 4 7}) & \mathbf{( 0 . 3 4 )} & \mathbf{( 0 . 3 9 )} & \mathbf{( 0 . 4 2 )} & \mathbf{( 0 . 3 2} & \mathbf{( 0 . 4 5 )} & (\mathbf{0 . 3 4}) & (\mathbf{0 . 3 6})\end{array}$

Parallel collaboration

\begin{tabular}{lllllllllll}
\hline AIC & 598.1 & 431.3 & 378.2 & 505.9 & 562.8 & 407.7 & 470.0 & 292.3 & 575.8 & 694.9 \\
BIC & 645.6 & 477.8 & 421.6 & 554.3 & 610.3 & 451.0 & 515.5 & 334.5 & 625.1 & 744.2
\end{tabular}

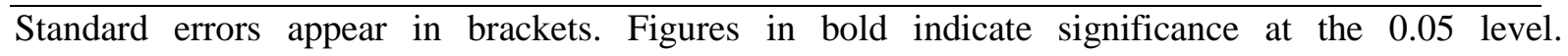




\begin{tabular}{|c|c|c|c|c|c|c|c|c|c|c|}
\hline & 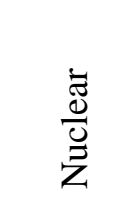 & 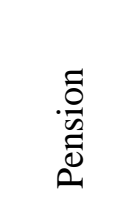 & 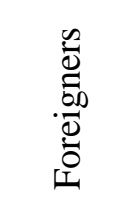 & $\begin{array}{l}\overrightarrow{\vec{D}} \\
\overrightarrow{0} \\
\vec{D} \\
0\end{array}$ & 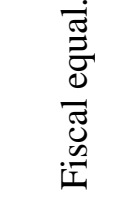 & 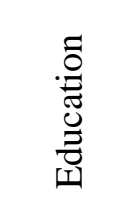 & $\begin{array}{l}\tilde{D} \\
\frac{0}{0} \\
\stackrel{0}{\theta}\end{array}$ & 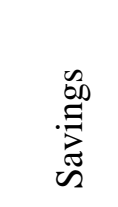 & $\begin{array}{l}\tilde{0} \\
0 \\
0 \\
0 \\
0\end{array}$ & 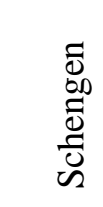 \\
\hline Edges & $\begin{array}{c}-3.19 \\
(1.72)\end{array}$ & $\begin{array}{l}-3.74 \\
(2.68)\end{array}$ & $\begin{array}{l}-6.75 \\
(1.68)\end{array}$ & $\begin{array}{c}-3.83 \\
(1.37)\end{array}$ & $\begin{array}{c}-5.14 \\
(11.08)\end{array}$ & $\begin{array}{l}-4.72 \\
(2.41)\end{array}$ & $\begin{array}{c}-4.78 \\
(2.66)\end{array}$ & $\begin{array}{l}-4.51 \\
(1.23)\end{array}$ & $\begin{array}{c}-5.42 \\
(1.86)\end{array}$ & $\begin{array}{l}-2.36 \\
(1.50)\end{array}$ \\
\hline Reciprocity & $\begin{array}{c}0.29 \\
(0.27)\end{array}$ & $\begin{array}{c}0.11 \\
(0.31)\end{array}$ & $\begin{array}{c}0.61 \\
(0.36)\end{array}$ & $\begin{array}{c}0.18 \\
(0.30)\end{array}$ & $\begin{array}{c}0.53 \\
(0.29)\end{array}$ & $\begin{array}{l}-0.55 \\
(0.37)\end{array}$ & $\begin{array}{c}0.07 \\
(0.33)\end{array}$ & $\begin{array}{l}-0.01 \\
(0.42)\end{array}$ & $\begin{array}{l}-0.40 \\
(0.30)\end{array}$ & $\begin{array}{l}-0.28 \\
(0.27\end{array}$ \\
\hline GWDSP & $\begin{array}{c}-0.23 \\
(0.08)\end{array}$ & $\begin{array}{c}0.23 \\
(0.68)\end{array}$ & $\begin{array}{l}-0.16 \\
(0.09)\end{array}$ & $\begin{array}{l}-\mathbf{- 0 . 2 5} \\
(0.05)\end{array}$ & $\begin{array}{c}-0.26 \\
(0.11)\end{array}$ & $\begin{array}{l}-0.10 \\
(0.16)\end{array}$ & $\begin{array}{c}-\mathbf{0 . 2 4} \\
(0.10)\end{array}$ & $\begin{array}{c}-\mathbf{0 . 3 1} \\
(\mathbf{0 . 0 9})\end{array}$ & $\begin{array}{c}-0.20 \\
(0.06)\end{array}$ & $\begin{array}{r}-\mathbf{- 0 . 1 8} \\
(\mathbf{0 . 0 8}\end{array}$ \\
\hline GWESP & $\begin{array}{c}-0.64 \\
(1.04 ?\end{array}$ & $\begin{array}{c}-1.98 \\
(1.81)\end{array}$ & $\begin{array}{c}0.39 \\
(0.94)\end{array}$ & $\begin{array}{l}-0.20 \\
(0.56)\end{array}$ & $\begin{array}{c}2.95 \\
(9.53)\end{array}$ & $\begin{array}{c}-0.96 \\
(1.23)\end{array}$ & $\begin{array}{c}-0.13 \\
(1.50)\end{array}$ & $\begin{array}{c}0.75 \\
(0.57)\end{array}$ & $\begin{array}{c}0.53 \\
(0.92)\end{array}$ & $\begin{array}{l}-1.00 \\
(0.70)\end{array}$ \\
\hline Reputation outdegree & $\begin{array}{c}0.20 \\
(\mathbf{0 . 0 3})\end{array}$ & $\begin{array}{c}0.32 \\
(0.06)\end{array}$ & $\begin{array}{c}0.37 \\
(0.07)\end{array}$ & $\begin{array}{c}0.27 \\
(0.04)\end{array}$ & $\begin{array}{c}0.01 \\
(0.03)\end{array}$ & $\begin{array}{c}0.34 \\
(0.08)\end{array}$ & $\begin{array}{c}0.27 \\
(\mathbf{0 . 0 5})\end{array}$ & $\begin{array}{c}0.24 \\
(0.06)\end{array}$ & $\begin{array}{c}0.24 \\
(0.04)\end{array}$ & $\begin{array}{r}0.18 \\
(\mathbf{0 . 0 4})\end{array}$ \\
\hline Reputation indegree & & & & & & & & & & \\
\hline Leading agency & $\begin{array}{c}0.83 \\
(1.00)\end{array}$ & $\begin{array}{c}5.13 \\
(1.14)\end{array}$ & $\begin{array}{c}0.55 \\
(0.47)\end{array}$ & $\begin{array}{c}4.92 \\
(0.87)\end{array}$ & $\begin{array}{c}0.01 \\
(0.41)\end{array}$ & $\begin{array}{c}1.55 \\
(0.57)\end{array}$ & $\begin{array}{c}3.23 \\
(1.46)\end{array}$ & $\begin{array}{c}1.93 \\
(0.50)\end{array}$ & $\begin{array}{c}0.80 \\
(0.61)\end{array}$ & $\begin{array}{r}0.74 \\
(0.32)\end{array}$ \\
\hline Government party & $\begin{array}{c}0.65 \\
(0.41)\end{array}$ & $\begin{array}{c}2.56 \\
(\mathbf{0 . 5 0})\end{array}$ & $\begin{array}{c}2.15 \\
(\mathbf{0 . 5 0})\end{array}$ & $\begin{array}{c}2.24 \\
(0.52)\end{array}$ & $\begin{array}{c}0.06 \\
(0.30)\end{array}$ & $\begin{array}{c}-0.24 \\
(0.50)\end{array}$ & $\begin{array}{c}1.18 \\
(0.42)\end{array}$ & $\begin{array}{c}0.45 \\
(0.40)\end{array}$ & $\begin{array}{c}2.39 \\
(0.41)\end{array}$ & $\begin{array}{c}0.39 \\
(0.39)\end{array}$ \\
\hline Peak association & $\begin{array}{c}0.23 \\
(0.32)\end{array}$ & $\begin{array}{c}2.25 \\
(0.39)\end{array}$ & $\begin{array}{l}-0.50 \\
(0.37)\end{array}$ & $\begin{array}{c}\text { 0.86 } \\
(\mathbf{0 . 3 2})\end{array}$ & $\begin{array}{c}\mathbf{- 0 . 8 8} \\
(\mathbf{0 . 4 1})\end{array}$ & $\begin{array}{c}-0.08 \\
(0.43)\end{array}$ & $\begin{array}{c}0.21 \\
(0.42)\end{array}$ & $\begin{array}{c}-0.12 \\
(0.45)\end{array}$ & $\begin{array}{c}1.55 \\
(\mathbf{0 . 3 4})\end{array}$ & $\begin{array}{c}0.70 \\
(0.38)\end{array}$ \\
\hline Participation & $\begin{array}{c}3.03 \\
(\mathbf{0 . 9 9})\end{array}$ & $\begin{array}{c}1.08 \\
(0.74)\end{array}$ & $\begin{array}{c}4.33 \\
(1.13)\end{array}$ & $\begin{array}{c}0.07 \\
(1.19)\end{array}$ & $\begin{array}{c}1.82 \\
(0.52)\end{array}$ & $\begin{array}{c}3.57 \\
(\mathbf{0 . 8 4})\end{array}$ & $\begin{array}{c}3.24 \\
(0.84)\end{array}$ & $\begin{array}{c}0.95 \\
(0.64)\end{array}$ & $\begin{array}{c}1.56 \\
(1.16)\end{array}$ & $\begin{array}{c}2.08 \\
(\mathbf{0 . 5 6})\end{array}$ \\
\hline Degree centrality & & & & & & & & & & \\
\hline Actor type homophily & $\begin{array}{c}0.31 \\
(0.22)\end{array}$ & $\begin{array}{c}0.46 \\
(0.32)\end{array}$ & $\begin{array}{c}0.01 \\
(0.30)\end{array}$ & $\begin{array}{l}-0.27 \\
(0.26)\end{array}$ & $\begin{array}{l}-0.03 \\
(0.25)\end{array}$ & $\begin{array}{c}0.10 \\
(0.36)\end{array}$ & $\begin{array}{c}0.01 \\
(0.31)\end{array}$ & $\begin{array}{c}0.42 \\
(0.35)\end{array}$ & $\begin{array}{c}0.24 \\
(0.27)\end{array}$ & $\begin{array}{l}-0.07 \\
(0.23)\end{array}$ \\
\hline Preference homophily & $\begin{array}{l}-0.06 \\
(0.18)\end{array}$ & $\begin{array}{c}-0.22 \\
(0.27)\end{array}$ & $\begin{array}{l}-0.14 \\
(0.23)\end{array}$ & $\begin{array}{c}0.31 \\
(0.22)\end{array}$ & $\begin{array}{c}0.30 \\
(0.25)\end{array}$ & $\begin{array}{c}\mathbf{0 . 9 0} \\
(\mathbf{0 . 3 2})\end{array}$ & $\begin{array}{c}0.06 \\
(0.20)\end{array}$ & $\begin{array}{c}1.44 \\
(0.31)\end{array}$ & $\begin{array}{c}-0.04 \\
(0.19)\end{array}$ & $\begin{array}{l}-0.17 \\
(0.18)\end{array}$ \\
\hline Collaboration & $\begin{array}{c}0.98 \\
(\mathbf{0 . 3 3})\end{array}$ & $\begin{array}{c}1.18 \\
(0.44)\end{array}$ & $\begin{array}{c}1.72 \\
(0.44)\end{array}$ & $\begin{array}{c}0.49 \\
(0.36)\end{array}$ & $\begin{array}{c}1.61 \\
(\mathbf{0 . 3 8})\end{array}$ & $\begin{array}{c}2.11 \\
(\mathbf{0 . 4 3})\end{array}$ & $\begin{array}{c}1.19 \\
(\mathbf{0 . 3 3})\end{array}$ & $\begin{array}{c}1.64 \\
(0.46)\end{array}$ & $\begin{array}{c}1.24 \\
(0.34)\end{array}$ & $\begin{array}{r}2.17 \\
(\mathbf{0 . 3 7})\end{array}$ \\
\hline Parallel collaboration & $\begin{array}{l}-0.06 \\
(0.07)\end{array}$ & $\begin{array}{c}0.18 \\
(0.11) \\
\end{array}$ & $\begin{array}{c}-0.00 \\
(0.08) \\
\end{array}$ & $\begin{array}{c}0.19 \\
(0.08) \\
\end{array}$ & $\begin{array}{c}0.58 \\
(0.12) \\
\end{array}$ & $\begin{array}{c}-0.16 \\
(0.09) \\
\end{array}$ & $\begin{array}{c}-0.05 \\
(0.09) \\
\end{array}$ & $\begin{array}{c}0.06 \\
(0.08) \\
\end{array}$ & $\begin{array}{c}0.17 \\
(0.09)\end{array}$ & $\begin{array}{r}0.01 \\
(0.09) \\
\end{array}$ \\
\hline AIC & 588.2 & 430.1 & 359.4 & 504.4 & 590.9 & 372.9 & 442.5 & 292.5 & 571.2 & 678.6 \\
\hline BIC & 644.3 & 485 & 410.6 & 561.6 & 647 & 424.1 & 496.2 & 342.3 & 629.4 & 736.8 \\
\hline
\end{tabular}

Standard errors appear in brackets. Figures in bold indicate significance at the 0.05 level. 


\begin{tabular}{|c|c|c|c|c|c|c|c|c|c|c|}
\hline & $\begin{array}{l}\frac{\dot{\Xi}}{\tilde{U}} \\
\frac{z}{z}\end{array}$ & $\begin{array}{l}\tilde{0} \\
.0 \\
\overline{0} \\
0\end{array}$ & 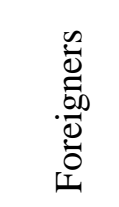 & $\begin{array}{l}\overrightarrow{\vec{D}} \\
\overrightarrow{0} \\
\overrightarrow{0}\end{array}$ & 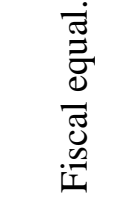 & 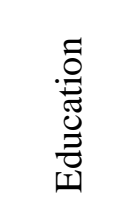 & 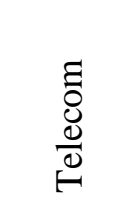 & 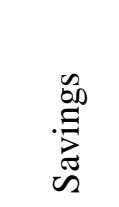 & 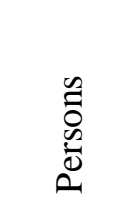 & 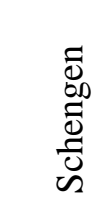 \\
\hline Edges & & & & & -7.48 & & -6.89 & -8.59 & -8.00 & -5.25 \\
\hline Reciprocity & -0.03 & -0.22 & 1.05 & 0.04 & 0.56 & -0.78 & 0.14 & -0.75 & -0.21 & $\begin{array}{l}-0.31 \\
(0.29)\end{array}$ \\
\hline GWDSP & $\begin{array}{c}0.03 \\
(0.10)\end{array}$ & $\begin{array}{c}1.30 \\
(1.29)\end{array}$ & $\begin{array}{c}-0.03 \\
(0.08)\end{array}$ & $\begin{array}{l}-0.03 \\
(0.07)\end{array}$ & $\begin{array}{l}-0.04 \\
(0.14)\end{array}$ & $\begin{array}{c}0.20 \\
(0.18)\end{array}$ & $\begin{array}{l}-0.13 \\
(0.12)\end{array}$ & $\begin{array}{c}0.02 \\
(' 0.10)\end{array}$ & $\begin{array}{l}-0.05 \\
(0.06)\end{array}$ & $\begin{array}{c}0.09 \\
(0.11)\end{array}$ \\
\hline GWESP & $\begin{array}{c}-0.82 \\
(1.14)\end{array}$ & $\begin{array}{l}-3.22 \\
(3.17)\end{array}$ & $\begin{array}{c}0.09 \\
(1.01)\end{array}$ & $\begin{array}{c}-0.90 \\
(0.48)\end{array}$ & $\begin{array}{c}3.74 \\
(11.97)\end{array}$ & $\begin{array}{c}-0.44 \\
(1.67)\end{array}$ & $\begin{array}{c}-0.13 \\
(1.31)\end{array}$ & $\begin{array}{c}0.11 \\
(0.61)\end{array}$ & $\begin{array}{c}0.62 \\
(0.90)\end{array}$ & $\begin{array}{l}-1.03 \\
(0.64)\end{array}$ \\
\hline Reputation outdegree & $\begin{array}{c}0.33 \\
(0.05)\end{array}$ & $\begin{array}{c}0.38 \\
(0.06)\end{array}$ & $\begin{array}{c}0.46 \\
(0.08)\end{array}$ & $\begin{array}{c}0.42 \\
(0.06)\end{array}$ & $\begin{array}{c}0.01 \\
(0.03)\end{array}$ & $\begin{array}{c}0.49 \\
(0.10)\end{array}$ & $\begin{array}{c}0.31 \\
(0.06)\end{array}$ & $\begin{array}{c}0.33 \\
(\mathbf{0 . 0 7})\end{array}$ & $\begin{array}{c}0.33 \\
(0.06)\end{array}$ & $\begin{array}{c}0.25 \\
(\mathbf{0 . 0 4})\end{array}$ \\
\hline Reputation indegree & $\begin{array}{c}0.32 \\
(0.05)\end{array}$ & $\begin{array}{c}0.36 \\
(0.07)\end{array}$ & $\begin{array}{c}\mathbf{0 . 3 7} \\
(\mathbf{0 . 0 7})\end{array}$ & $\begin{array}{c}0.35 \\
(0.05)\end{array}$ & $\begin{array}{c}0.23 \\
(0.06)\end{array}$ & $\begin{array}{c}0.43 \\
(0.08)\end{array}$ & $\begin{array}{c}0.11 \\
(0.05)\end{array}$ & $\begin{array}{c}0.46 \\
(0.09)\end{array}$ & $\begin{array}{c}0.27 \\
(0.05)\end{array}$ & $\begin{array}{r}0.24 \\
(0.05)\end{array}$ \\
\hline Leading agency & $\begin{array}{c}0.22 \\
(1.02)\end{array}$ & $\begin{array}{c}0.58 \\
(1.50)\end{array}$ & $\begin{array}{c}0.25 \\
(0.66)\end{array}$ & $\begin{array}{c}1.17 \\
(1.74)\end{array}$ & $\begin{array}{l}-0.47 \\
(0.54)\end{array}$ & $\begin{array}{c}0.16 \\
(0.55)\end{array}$ & $\begin{array}{c}4.46 \\
(1.43)\end{array}$ & $\begin{array}{l}-0.16 \\
(0.69)\end{array}$ & $\begin{array}{c}0.35 \\
(0.91)\end{array}$ & $\begin{array}{c}0.08 \\
(0.34)\end{array}$ \\
\hline Government party & $\begin{array}{c}0.03 \\
(0.46)\end{array}$ & $\begin{array}{l}-0.80 \\
(0.84)\end{array}$ & $\begin{array}{c}0.22 \\
(' 0.70)\end{array}$ & $\begin{array}{c}0.18 \\
(0.98)\end{array}$ & $\begin{array}{c}-\mathbf{- 0 . 7 6} \\
(0.38)\end{array}$ & $\begin{array}{c}0.46 \\
(0.65)\end{array}$ & $\begin{array}{c}0.65 \\
(0.44)\end{array}$ & $\begin{array}{c}0.15 \\
(0.57)\end{array}$ & $\begin{array}{c}-0.04 \\
(0.58)\end{array}$ & $\begin{array}{c}0.29 \\
(0.42)\end{array}$ \\
\hline Peak association & $\begin{array}{c}0.33 \\
(0.44)\end{array}$ & $\begin{array}{l}-0.56 \\
(0.61)\end{array}$ & $\begin{array}{c}0.12 \\
(0.41)\end{array}$ & $\begin{array}{c}0.26 \\
(0.42)\end{array}$ & $\begin{array}{l}-0.61 \\
(0.45)\end{array}$ & $\begin{array}{c}-0.10 \\
(0.51)\end{array}$ & $\begin{array}{c}0.24 \\
(0.45)\end{array}$ & $\begin{array}{l}-0.62 \\
(0.74)\end{array}$ & $\begin{array}{c}0.10 \\
(0.47)\end{array}$ & $\begin{array}{l}-0.03 \\
(0.56)\end{array}$ \\
\hline Participation & $\begin{array}{c}-0.05 \\
(1.31)\end{array}$ & $\begin{array}{c}0.45 \\
(0.83)\end{array}$ & $\begin{array}{l}-0.08 \\
(1.40)\end{array}$ & $\begin{array}{l}-0.20 \\
(1.42)\end{array}$ & $\begin{array}{l}-0.08 \\
(0.53)\end{array}$ & $\begin{array}{c}0.20 \\
(0.83)\end{array}$ & $\begin{array}{c}2.44 \\
(0.82)\end{array}$ & $\begin{array}{l}-0.16 \\
(0.84)\end{array}$ & $\begin{array}{l}-0.68 \\
(1.23)\end{array}$ & $\begin{array}{l}-0.22 \\
(0.59)\end{array}$ \\
\hline Degree centrality & $\begin{array}{c}-1.07 \\
(1.91)\end{array}$ & $\begin{array}{c}-1.13 \\
(1.81)\end{array}$ & $\begin{array}{c}-0.97 \\
(2.18)\end{array}$ & $\begin{array}{l}-2.39 \\
(2.01)\end{array}$ & $\begin{array}{l}-1.44 \\
(2.19)\end{array}$ & $\begin{array}{c}-3.31 \\
(1.78)\end{array}$ & $\begin{array}{c}2.23 \\
(1.14)\end{array}$ & $\begin{array}{l}-1.91 \\
(2.22)\end{array}$ & $\begin{array}{c}-0.80 \\
(1.70)\end{array}$ & $\begin{array}{l}-1.07 \\
(1.23)\end{array}$ \\
\hline Actor type homophily & $\begin{array}{c}0.26 \\
(0.27)\end{array}$ & $\begin{array}{c}0.77 \\
(\mathbf{0 . 3 8})\end{array}$ & $\begin{array}{c}0.35 \\
(0.35)\end{array}$ & $\begin{array}{c}0.03 \\
(0.32)\end{array}$ & $\begin{array}{c}0.13 \\
(0.26)\end{array}$ & $\begin{array}{c}0.13 \\
(0.41)\end{array}$ & $\begin{array}{c}-0.03 \\
(0.35)\end{array}$ & $\begin{array}{c}0.86 \\
(0.45)\end{array}$ & $\begin{array}{c}0.51 \\
(0.30)\end{array}$ & $\begin{array}{c}0.20 \\
(0.26)\end{array}$ \\
\hline Preference homophily & $\begin{array}{c}0.20 \\
(0.23)\end{array}$ & $\begin{array}{l}-0.24 \\
(0.28)\end{array}$ & $\begin{array}{c}0.40 \\
(0.31)\end{array}$ & $\begin{array}{c}0.26 \\
(0.25)\end{array}$ & $\begin{array}{c}0.34 \\
(0.27)\end{array}$ & $\begin{array}{c}0.82 \\
(0.37)\end{array}$ & $\begin{array}{c}-0.00 \\
(0.01)\end{array}$ & $\begin{array}{c}1.43 \\
(0.36)\end{array}$ & $\begin{array}{c}0.03 \\
(0.21)\end{array}$ & $\begin{array}{l}-0.07 \\
(0.19)\end{array}$ \\
\hline Collaboration & $\begin{array}{c}0.58 \\
(0.41)\end{array}$ & $\begin{array}{c}1.12 \\
(0.47)\end{array}$ & $\begin{array}{c}1.15 \\
(0.55)\end{array}$ & $\begin{array}{c}0.93 \\
(0.44)\end{array}$ & $\begin{array}{c}1.36 \\
(0.40)\end{array}$ & $\begin{array}{c}2.19 \\
(0.49)\end{array}$ & $\begin{array}{c}0.60 \\
(0.35)\end{array}$ & $\begin{array}{c}1.46 \\
(0.54)\end{array}$ & $\begin{array}{c}0.93 \\
(0.38)\end{array}$ & $\begin{array}{r}1.86 \\
(\mathbf{0 . 3 9})\end{array}$ \\
\hline Parallel collaboration & $\begin{array}{c}-0.04 \\
(0.09)\end{array}$ & $\begin{array}{c}0.10 \\
(0.12) \\
\end{array}$ & $\begin{array}{c}-0.21 \\
(0.10) \\
\end{array}$ & $\begin{array}{c}0.10 \\
(0.10) \\
\end{array}$ & $\begin{array}{c}0.57 \\
(0.12) \\
\end{array}$ & $\begin{array}{c}-0.19 \\
(0.11) \\
\end{array}$ & $\begin{array}{c}0.03 \\
(0.11) \\
\end{array}$ & $\begin{array}{c}0.09 \\
(0.10) \\
\end{array}$ & $\begin{array}{c}0.10 \\
(0.10) \\
\end{array}$ & $\begin{array}{r}-0.08 \\
(0.08) \\
\end{array}$ \\
\hline $\begin{array}{l}\text { AIC } \\
\text { BIC }\end{array}$ & $\begin{array}{l}463.1 \\
527.8\end{array}$ & $\begin{array}{l}377.3 \\
440.7\end{array}$ & $\begin{array}{l}347.5 \\
402.6\end{array}$ & $\begin{array}{l}387.5 \\
453.4\end{array}$ & $\begin{array}{c}542 \\
606.7\end{array}$ & $\begin{array}{l}284.6 \\
343.7\end{array}$ & $\begin{array}{l}410.3 \\
472.3\end{array}$ & $\begin{array}{c}238 \\
295.5\end{array}$ & $\begin{array}{l}535.7 \\
598.4\end{array}$ & $\begin{array}{l}605.2 \\
672.4\end{array}$ \\
\hline
\end{tabular}

Standard errors appear in brackets. Figures in bold indicate significance at the 0.05 level. 


\begin{tabular}{|c|c|c|c|c|c|c|c|c|c|c|}
\hline & 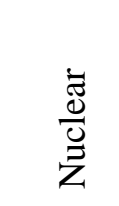 & 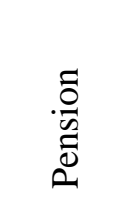 & 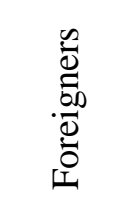 & $\begin{array}{l}\vec{D} \\
\vec{\infty} \\
\vec{D} \\
\vec{n}\end{array}$ & 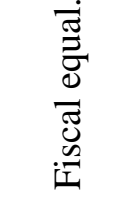 & 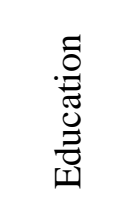 & 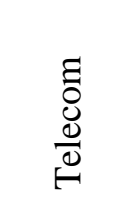 & 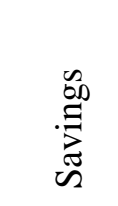 & $\begin{array}{l}\tilde{0} \\
\overline{0} \\
\overline{0} \\
\tilde{0}\end{array}$ & 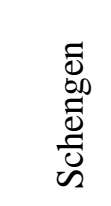 \\
\hline Edges & $\begin{array}{c}-4.65 \\
(0.48)\end{array}$ & $\begin{array}{l}-6.13 \\
(0.75)\end{array}$ & $\begin{array}{l}-6.85 \\
(0.79)\end{array}$ & $\begin{array}{l}-4.86 \\
(0.53)\end{array}$ & $\begin{array}{l}-5.74 \\
(0.54)\end{array}$ & $\begin{array}{c}-7.48 \\
(0.95)\end{array}$ & $\begin{array}{l}-6.74 \\
(0.70)\end{array}$ & $\begin{array}{c}-6.28 \\
(0.81)\end{array}$ & $\begin{array}{c}-7.17 \\
(0.67)\end{array}$ & $\begin{array}{c}-4.72 \\
(0.44)\end{array}$ \\
\hline \multicolumn{11}{|l|}{ Reciprocity } \\
\hline \multicolumn{11}{|l|}{ GWDSP } \\
\hline \multicolumn{11}{|l|}{ GWESP } \\
\hline Reputation outdegree & $\begin{array}{c}0.25 \\
(0.03)\end{array}$ & $\begin{array}{c}0.31 \\
(\mathbf{0 . 0 4})\end{array}$ & $\begin{array}{c}0.39 \\
(0.06)\end{array}$ & $\begin{array}{c}0.28 \\
(\mathbf{0 . 0 3})\end{array}$ & $\begin{array}{c}0.25 \\
(0.03)\end{array}$ & $\begin{array}{c}0.37 \\
(\mathbf{0 . 0 6})\end{array}$ & $\begin{array}{c}0.33 \\
(0.04)\end{array}$ & $\begin{array}{c}0.36 \\
(0.06)\end{array}$ & $\begin{array}{c}0.29 \\
(\mathbf{0 . 0 3})\end{array}$ & $\begin{array}{c}0.22 \\
(\mathbf{0 . 0 2})\end{array}$ \\
\hline \multicolumn{11}{|l|}{ Reputation indegree } \\
\hline Leading agency & $\begin{array}{c}0.83 \\
(0.86)\end{array}$ & $\begin{array}{c}4.59 \\
(1.13)\end{array}$ & $\begin{array}{c}0.50 \\
(0.56)\end{array}$ & $\begin{array}{c}4.11 \\
(1.03)\end{array}$ & $\begin{array}{l}-1.28 \\
(0.61)\end{array}$ & $\begin{array}{c}1.33 \\
(0.61)\end{array}$ & $\begin{array}{c}3.39 \\
(1.26)\end{array}$ & $\begin{array}{c}1.81 \\
(0.54)\end{array}$ & $\begin{array}{c}-1.89 \\
(0.72)\end{array}$ & $\begin{array}{c}0.62 \\
(0.32)\end{array}$ \\
\hline Government party & $\begin{array}{c}\mathbf{0 . 8 0} \\
(\mathbf{0 . 4 0})\end{array}$ & $\begin{array}{c}2.05 \\
(\mathbf{0 . 5 3})\end{array}$ & $\begin{array}{c}2.49 \\
(\mathbf{0 . 5 3})\end{array}$ & $\begin{array}{c}2.08 \\
(0.62)\end{array}$ & $\begin{array}{c}0.75 \\
(\mathbf{0 . 3 3})\end{array}$ & $\begin{array}{c}-0.01 \\
(0.50)\end{array}$ & $\begin{array}{c}0.75 \\
(0.42)\end{array}$ & $\begin{array}{c}1.10 \\
(0.46)\end{array}$ & $\begin{array}{c}1.74 \\
(0.46)\end{array}$ & $\begin{array}{c}0.42 \\
(0.38)\end{array}$ \\
\hline Peak association & $\begin{array}{c}-0.42 \\
(0.36)\end{array}$ & $\begin{array}{c}1.93 \\
(0.40)\end{array}$ & $\begin{array}{l}-0.21 \\
(0.38)\end{array}$ & $\begin{array}{c}0.97 \\
(\mathbf{0 . 3 3})\end{array}$ & $\begin{array}{l}-0.74 \\
(0.48)\end{array}$ & $\begin{array}{c}0.22 \\
(0.49)\end{array}$ & $\begin{array}{c}0.17 \\
(0.46)\end{array}$ & $\begin{array}{c}-0.26 \\
(0.59)\end{array}$ & $\begin{array}{c}0.90 \\
(0.39)\end{array}$ & $\begin{array}{c}0.54 \\
(0.40)\end{array}$ \\
\hline Participation & $\begin{array}{c}-0.06 \\
(1.03)\end{array}$ & $\begin{array}{c}0.81 \\
(0.72)\end{array}$ & $\begin{array}{c}4.33 \\
(1.00)\end{array}$ & $\begin{array}{c}0.46 \\
(0.93)\end{array}$ & $\begin{array}{c}1.71 \\
(0.53)\end{array}$ & $\begin{array}{c}2.26 \\
(0.77)\end{array}$ & $\begin{array}{c}3.33 \\
(0.65)\end{array}$ & $\begin{array}{c}0.22 \\
(0.74)\end{array}$ & $\begin{array}{c}1.95 \\
(1.00)\end{array}$ & $\begin{array}{c}1.58 \\
(0.52)\end{array}$ \\
\hline Degree centrality & $\begin{array}{c}7.83 \\
(1.43)\end{array}$ & $\begin{array}{c}3.56 \\
(1.61)\end{array}$ & $\begin{array}{c}4.70 \\
(1.63)\end{array}$ & $\begin{array}{c}1.07 \\
(1.51)\end{array}$ & $\begin{array}{c}9.53 \\
(1.75)\end{array}$ & $\begin{array}{c}6.47 \\
(1.28)\end{array}$ & $\begin{array}{c}4.50 \\
(0.90)\end{array}$ & $\begin{array}{c}7.51 \\
(1.47)\end{array}$ & $\begin{array}{c}8.05 \\
(1.28)\end{array}$ & $\begin{array}{c}3.93 \\
(0.92)\end{array}$ \\
\hline Actor type homophily & $\begin{array}{c}0.34 \\
(0.24)\end{array}$ & $\begin{array}{c}0.53 \\
(0.32)\end{array}$ & $\begin{array}{c}0.11 \\
(0.33)\end{array}$ & $\begin{array}{l}-0.29 \\
(0.27)\end{array}$ & $\begin{array}{c}0.36 \\
(0.29)\end{array}$ & $\begin{array}{c}0.12 \\
(0.35)\end{array}$ & $\begin{array}{c}-0.03 \\
(0.27)\end{array}$ & $\begin{array}{c}0.52 \\
(0.38)\end{array}$ & $\begin{array}{c}0.31 \\
(0.26)\end{array}$ & $\begin{array}{c}0.05 \\
(0.23)\end{array}$ \\
\hline Preference homophily & $\begin{array}{c}0.10 \\
(0.20)\end{array}$ & $\begin{array}{l}-0.24 \\
(0.27)\end{array}$ & $\begin{array}{c}0.16 \\
(0.29)\end{array}$ & $\begin{array}{c}0.29 \\
(0.21)\end{array}$ & $\begin{array}{c}0.68 \\
(0.29)\end{array}$ & $\begin{array}{c}0.91 \\
(0.33)\end{array}$ & $\begin{array}{c}0.00 \\
(0.21)\end{array}$ & $\begin{array}{c}1.48 \\
(0.32)\end{array}$ & $\begin{array}{c}-0.10 \\
(0.20)\end{array}$ & $\begin{array}{l}-0.22 \\
(0.18)\end{array}$ \\
\hline Collaboration & $\begin{array}{c}0.49 \\
(0.36)\end{array}$ & $\begin{array}{c}1.07 \\
(0.44)\end{array}$ & $\begin{array}{c}1.58 \\
(0.52)\end{array}$ & $\begin{array}{c}0.30 \\
(0.35)\end{array}$ & $\begin{array}{c}0.89 \\
(0.43)\end{array}$ & $\begin{array}{c}1.48 \\
(0.39)\end{array}$ & $\begin{array}{c}0.64 \\
(0.34)\end{array}$ & $\begin{array}{c}1.05 \\
(0.44)\end{array}$ & $\begin{array}{c}0.80 \\
(0.33)\end{array}$ & $\begin{array}{c}1.72 \\
(0.34)\end{array}$ \\
\hline Parallel collaboration & $\begin{array}{c}-0.06 \\
(0.08)\end{array}$ & $\begin{array}{c}0.16 \\
(0.11) \\
\end{array}$ & $\begin{array}{l}-0.17 \\
(0.09) \\
\end{array}$ & $\begin{array}{c}0.22 \\
(0.09) \\
\end{array}$ & $\begin{array}{c}0.43 \\
(0.13) \\
\end{array}$ & $\begin{array}{c}-0.12 \\
(0.09) \\
\end{array}$ & $\begin{array}{c}-0.02 \\
(0.10) \\
\end{array}$ & $\begin{array}{c}0.08 \\
(0.09) \\
\end{array}$ & $\begin{array}{c}0.16 \\
(0.09) \\
\end{array}$ & $\begin{array}{l}-0.03 \\
(0.09) \\
\end{array}$ \\
\hline AIC & 560.6 & 425.7 & 347.7 & 520.6 & 477.0 & 345.6 & 414.6 & 272.3 & 538.9 & 669.4 \\
\hline BIC & 608.0 & 472.2 & 391.0 & 569.0 & 524.5 & 389.0 & 460.0 & 314.5 & 588.2 & 718.7 \\
\hline
\end{tabular}

Standard errors appear in brackets. Figures in bold indicate significance at the 0.05 level. 